\title{
PERAN MRI DALAM PENCITRAAN DIAGNOSTIK TUMOR CEREBELLOPONTINE ANGLE (CPA)
}

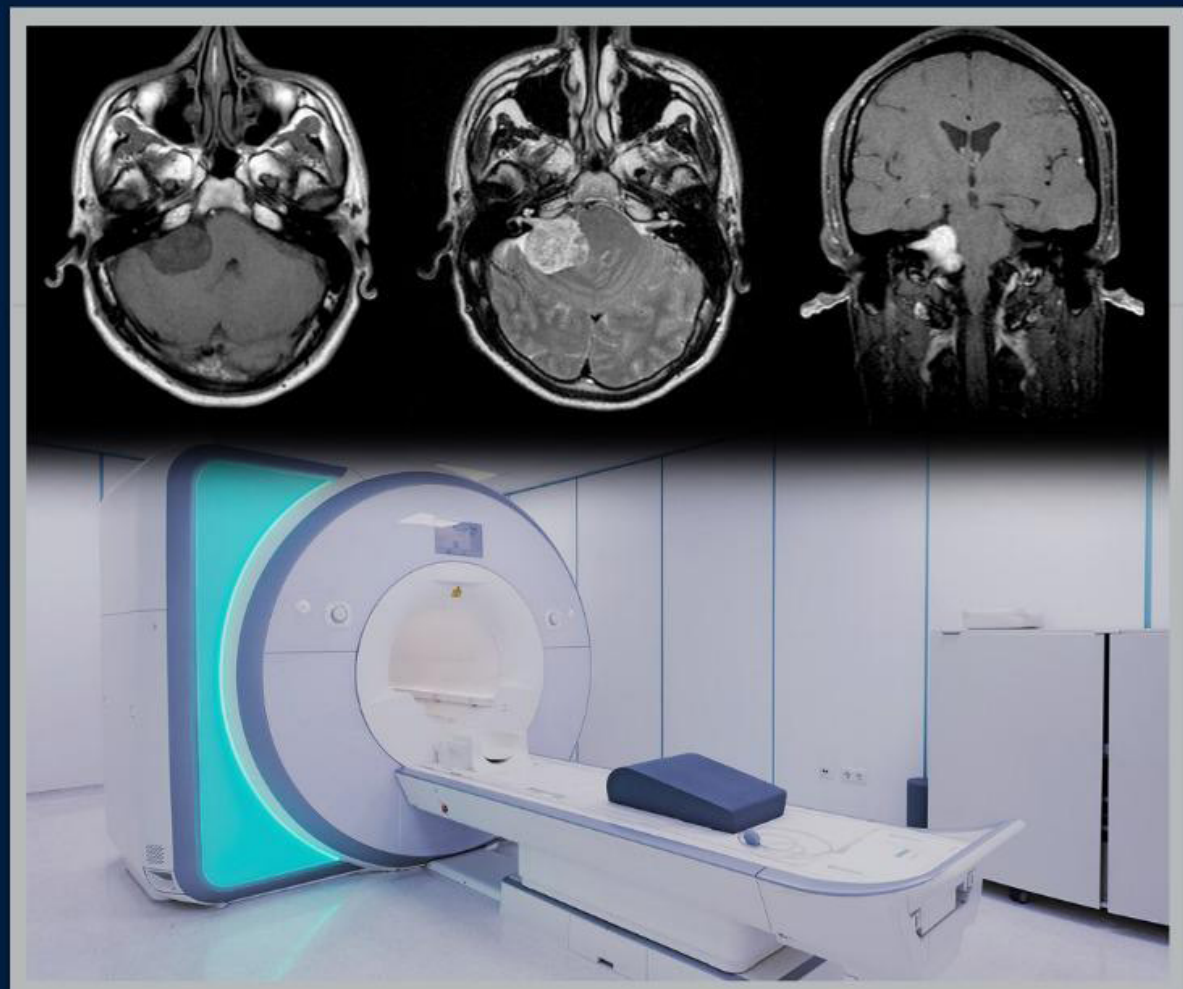

Disusun oleh:

dr. Firman Parulian Sitanggang, Sp.Rad (K) RI, M.Kes dr. I Made Dwija Putra Ayusta, Sp.Rad (K) dr. Ni Made Putri Suastari, S.Ked.

DEPARTEMEN RADIOLOGI

FAKULTAS KEDOKTERAN UNIVERSITAS UDAYANA RSUP SANGLAH-DENPASAR 2021 


\section{PERAN MRI DALAM PENCITRAAN DIAGNOSTI TUMOR CEREBELLOPONTINE ANGLE (CPA)}

\section{Disusun oleh:}

dr. Firman Parulian Sitanggang, Sp.Rad (K) Rl, M.Kes. dr. I Made Dwija Putra Ayusta, Sp.Rad (K) dr. Ni Made Putri Suastari, S.Ked.

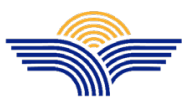

PENERBIT

PANUDUH ATMA WARAS

J. ByPass Ngurah Rai Nomor: 888 xx, Denpasar, Bali - Indonesia

(0361) 6209990

(+62)82236180725

info@baswarapress.com

panuduhatmawaras@gmail.com 


\section{PERAN MRI DALAM PENCITRAAN DIAGNOSTIK TUMOR CEREBELLOPONTINE ANGLE (CPA)}

Penulis:

dr. Firman Parulian Sitanggang, Sp.Rad (K) RI, M.Kes.

dr. I Made Dwija Putra Ayusta, Sp.Rad (K)

dr. Ni Made Putri Suastari, S.Ked.

ISBN

: 978-623-97955-7-3

ISBN (PDF) : 978-623-97955-6-6

Copyright @ September 2021

Hak Cipta dilindungi oleh Undang-Undang. Pertama kali diterbitkan di Indonesia dalam Bahasa Indonesia oleh PANUDUH ATMA WARAS bekerjasama dengan DEPARTMEN RADIOLOGI FAKULTAS KEDOKTERAN UNIVERSITAS UDAYANA, dan RSUP SANGLAH DENPASAR. Penggunaan material dalam karya ini diatur dalam Lisensi Publik Creative Commons 4.0 Atribusi-NonKomersial-TanpaTurunan (CC-BY-ND). Pengguna dapat mengutip konten dalam karya ini dengan memberi kredit yang sepantasnya kepada penulis asli karya ini. Dilarang menggunakan karya ini untuk kepentingan komersial dalam bentuk apapun. Dilarang mengubah dan menyebarluaskan isi karya ini dalam bentuk apa pun tanpa izin tertulis dari penulis.

\section{PENERBIT}

PANUDUH ATMA WARAS

Jl. ByPass Ngurah Rai Nomor: 888 xx, Denpasar, Bali - Indonesia (0361) 6209990; (+62)82236180725 info@baswarapress.com panuduhatmawaras@gmail.com 


\section{PERAN MRI DALAM PENCITRAAN DIAGNOSTI TUMOR CEREBELLOPONTINE ANGLE (CPA)}

Disusun oleh:

dr. Firman Parulian Sitanggang, Sp.Rad (K) RI, M.Kes.

dr. I Made Dwija Putra Ayusta, Sp.Rad (K)

dr. Ni Made Putri Suastari, S.Ked.

DEPARTEMEN RADIOLOGI

FAKULTAS KEDOKTERAN UNIVERSITAS UDAYANA

RSUP SANGLAH-DENPASAR

2021 


\section{PRAKATA}

Puji syukur penulis panjatkan kepada Tuhan Yang Maha Esa atas petunjuk dan perkenannya kami, penulis telah berhasil menyusun buku Peran MRI dalam Pencitraan Diagnostik Tumor Cerebellopontine Angle (CPA).

Perkembangan ilmu pengetahuan dan teknologi telah membawa kemajuan yang sangat pesat di berbagai bidang. Tumor CPA secara klinis tidak spesifik dan gejala yang muncul tidak terkait dengan sifat lesi itu sendiri, tetapi berhubungan dengan struktur neurovaskular atau struktur otak yang terlibat dengan lesi tersebut. Diagnosis mungkin sulit dibuat karena berbagai jenis sel dan asal tumor tersebut. Oleh karena tumor CPA yang berasal dari spektrum yang sangat luas sehingga menjadi tantangan dalam penegakkan diagnosis. Untuk dapat mencakup seluruh spektrum tumor yang berpotensi ditemukan di CPA, maka diperlukan pencitraan neuroimaging terkait yang perlu diketahui oleh ahli radiologi untuk membuat diagnosis yang relevan secara klinis dalam menegakkan diagnosis pra operasi yang lebih akurat.

Buku ini dapat dijadikan buku ajar bagi mahasiswa Program Pendidikan Dokter Spesialis (PPDS) dan Dokter Muda di Departemen Radiologi dengan harapan dapat memberikan manfaat dalam menangani kasus-kasus dengan kecurigaan tumor di regio CPA.

Akhir kata, penulis menyadari bahwa buku ini masih jauh dari sempurna. Oleh karena itu, penulis mengharapkan kritik dan saran yang bersifat konstruktif demi penyempurnaan buku ini untuk selanjutnya dapat menjadi lebih baik dan mempunyai potensi untuk dikembangkan. 


\section{DAFTAR ISI}

Halaman Judul ..................................................................... i

Halaman Balik Judul........................................................................... ii

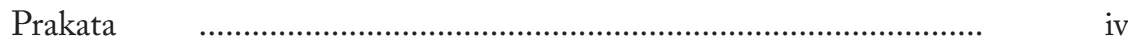

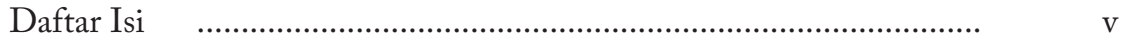

Daftar Gambar ................................................................................... vi

Daftar Tabel .................................................................................. vii

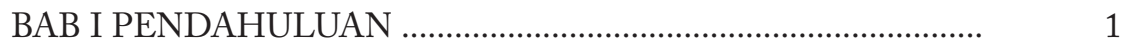

BAB II GAMBARAN HASIL MRI PADA TUMOR CPA............. 3

2.1 Anatomi ................................................................. 3

2.2 Definisi Tumor CPA …................................................... $\quad 5$

2.3 Etiologi Tumor CPA …...................................................

2.4 Patofisiologi Tumor CPA ….............................................. 5

2.5 Gejala Klinis ..................................................................

2.6 Pemeriksaan Radiologi ..................................................... 8

2.7 Jenis-Jenis Tumor CPA ....................................... 11

2.7.1 Tumor yang Enhance .............................................. 12

2.7.1.1 Tumor ekstra-aksial yang berasal dari CPA 12

2.7.1.2 Tumor intra-aksial dan intraventricular .... 25

2.7.1.3 Lesi Basis Cranii ...................................... $\quad 35$

2.7.2 Tumor yang Tidak Enhance ................................... 38

2.7.2.1 Lesi intensitas sinyal rendah pada T1WI.... $\quad 38$

2.7.2.2 Lesi intensitas sinyal tinggi pada T1WI..... 43

BAB III PENUTUP .................................................................... 47

DAFTAR PUSTAKA …................................................................ 48 


\section{DAFTAR GAMBAR}

Gambar 1 Anatomi CPA ............................................. 3

Gambar 2 Anatomi CPA dan hubungannya dengan tulang temporal..............................................................

Gambar 3 Alogaritma pendekatan untuk diagnosis tumor CPA.

Gambar 4 Schwannoma vestibular.

Gambar 5 Sisa pasca terapi dari vestibular schwannoma

Gambar 6 Schwannoma saraf wajah kiri

Gambar 7 Schwannoma foramen jugularis

Gambar 8 Meningioma CPA kiri

Gambar 9 Metastasis intra dan ekstra-aksial

Gambar 10 Aneurisma vertebrobasilar

Gambar 11 Kavernoma CPA kanan.............................................

Gambar 12 Sarkoidosis................................................................

Gambar 13 Tuberkulom...............................................................

Gambar 14 Penyakit Erdheim-Chester..................................... 25

Gambar 15 Limfoma otak primer .............................................. 27

Gambar 16 Glioma batang otak............................................... 28

Gambar 17 Metastasis dari kanker usus besar............................. $\quad 29$

Gambar 18 Hemangioblastoma................................................... 30

Gambar 19 Medulloblastoma..................................................... $\quad 31$

Gambar 20 Papiloma................................................................... 
Gambar 21 Ependymona........................................................

Gambar 22 Dysembryoplastic neuroepithelial tumour................................................................ 34

Gambar 23 Paraganglioma.................................................. $\quad 35$

Gambar 24 Kondroma raksasa................................................. 36

Gambar 25 Tumor kantung endolimfatik................................ 38

Gambar 26 Kista epidermoid.................................................. 40

Gambar 27 Kista arachnoid....................................................... 41

Gambar 28 Neurosistiserksis..................................................... 42

Gambar 29 Lipoma..................................................................... 43

Gambar 30 Kista dermoid.........................................................

Gambar 31 Kista neurenterik................................................... 45

Gambar 32 Granuloma kolesterol................................................ 46 


\section{DAFTAR TABEL}

Tabel 1 Ringkasan temuan difusi, perfusi, dan MR spectroscopy .......................................................... 


\section{BAB I}

\section{PENDAHULUAN}

Tumor Cerebellopontine Angle (CPA) merupakan jenis neoplasma terbanyak yang ditemukan di fossa posterior dengan angka kejadian sebesar 5-10\% dari seluruh angka kejadian tumor intrakranial. Mayoritas tumor di CPA adalah schwannoma vestibular sebesar 70\%-80\%, diikuti meningioma 5-12\% dan kista epidermoid 2-6\%, serta tumor CPA lainnya, yang masing-masing menyumbang sekitar 1\%. Angka kejadian tumor ganas atau tumor metastasis hanya $2 \%$ dari keseluruhan tumor CPA. ${ }^{1}$

CPA merupakan suatu daerah berbentuk segitiga pada fossa posterior yang dibatasi oleh tulang temporal, cerebellum dan pons. Pada daerah ini sering terdapat massa abnormal yang kemudian disebut sebagai tumor CPA. Tumor yang tumbuh pada daerah ini dapat menyebabkan berbagai gejala neurologis yang serius bahkan kematian jika tumor tumbuh membesar dan menekan batang otak. Gejala yang sering terjadi berupa kehilangan pendengaran ipsilateral, hipestesi pada wajah dan gangguan keseimbangan. Pada gambaran pencitraan otak sering didapati adanya hidrosefalus. ${ }^{1}$

Jenis tumor yang sering dijumpai pada CPA adalah vestibular schwannoma (neuroma akustik). Jenis ini merupakan yang paling banyak ditemukan, mencapai 75\% dari keseluruhan tomur pada CPA. Jenis-jenis lainnya yang jarang terjadi adalah meningioma, kista epidermoid, kista arakhnoid, schwannoma fasial, hemangioma, papiloma pleksus choroidalis, paragangliomas dan tumor metastase. ${ }^{2}$

Tumor CPA secara klinis tidak spesifik dan gejala yang muncul tidak terkait dengan sifat lesi itu sendiri, tetapi berhubungan dengan struktur neurovaskular atau struktur otak yang terlibat dengan lesi tersebut. Diagnosis mungkin sulit dibuat karena berbagai jenis sel dan asal tumor tersebut. Oleh karena tumor CPA yang berasal dari spektrum yang sangat luas sehingga menjadi tantangan dalam penegakkan diagnosis. Untuk dapat mencakup seluruh spektrum tumor yang berpotensi ditemukan di CPA, maka diperlukan pencitraan neuroimaging terkait yang perlu diketahui oleh ahli radiologi untuk membuat diagnosis yang relevan secara klinis. Melalui pencitraan radiologi tersebut akan dievaluasi lokasi asal dari tumor, bentuk dan margin, kepadatan, intensitas sinyal dan penyangatan kontras dalam menegakkan diagnosis pra operasi yang lebih akurat. Diagnosis dan tatalaksana tumor CPA 
diharapkan akan semakin baik, seiring dengan berkembangnya teknik imaging, teknik pembedahan mikro dan radiosurgery. ${ }^{2}$ 


\section{BAB II}

\section{GAMBARAN HASIL MRI PADA TUMOR CPA}

\subsection{Anatomi}

Sisterna CPA adalah ruang subarachnoid pada fossa posterior yang berisi jalur saraf kranial dan pembuluh darah yang dikelilingi cairan serebrospinal (CSF). CPA merupakan struktur dengan bentuk kira-kira menyerupai segitiga. Bagian atasnya dibatasi oleh tentorium serebelli, bagian bawahnya dibatasi oleh tonsilla serebelli dan oliva medullaris. Batas anterior adalah permukaan dura posterior dari tulang petrous dan klivus, sedangkan batas posterior adalah permukaan ventral dari pons dan cerebellum. Batas medialnya berupa sisterna pons dan medula, dan bagian apeksnya adalah daerah recessus lateralis ventrikel empat. Pintu lateral dari ventrikel IV, foramen Luschka, merupakan jalan masuk ke CPA. Nervus kranialis V-XI melintasi batas atas dan bawah CPA. Pada bagian atas dan bawah dari CPA melintas beberapa nervus kranialis yaitu nervus V, nervus VII dan nervus VIII yang kemudian menuju Internal Auditory Canal (IAC). ${ }^{3}$

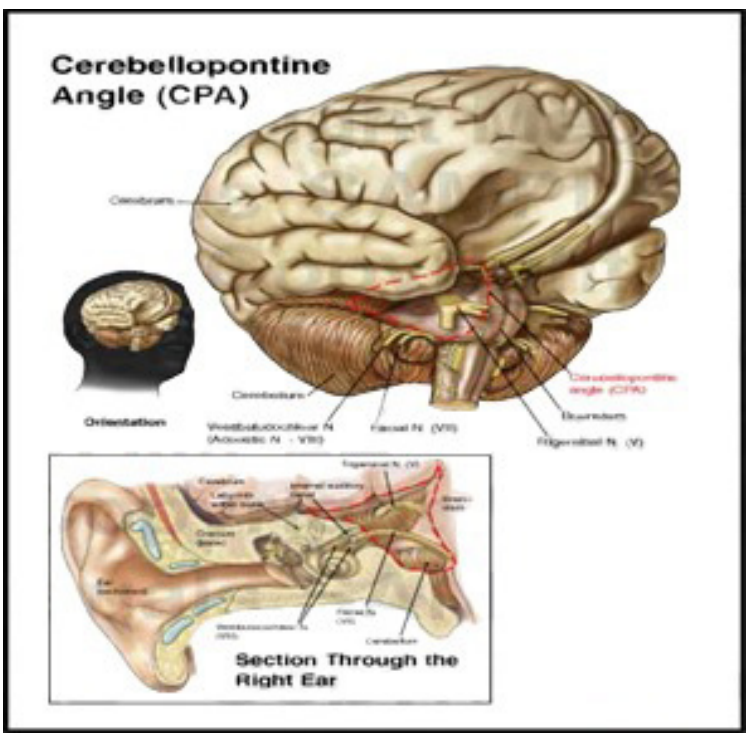

Gambar 1. Anatomi CPA. ${ }^{3}$ 
Nervus kranialis VII dan VIII ditutupi oleh myelin sentral yang disediakan oleh sel neuroglial ketika menyebrangi CPA dan membawa bagian lengan dura fossa posterior ke kanalis auditorius interna (internal auditory canal = IAC). Transisi dari myelin perifer dilakukan oleh sel Schwann yang muncul di pintu medial dari IAC. Nervus vestibulokoklearis terbagi dalam tiga cabang, yaitu n. koklearis, n. vestibularis superior dan inferior pada sisi lateral CPA atau medial IAC. IAC sendiri dibagi dalam empat kuadran oleh ujung vertikal yang disebut Bill's bar, dan ujung transversa. Nervus VII berada di kuadran anterosuperior yang juga anterior dari n. vestibularis superior dan superior dari n. koklearis. Sedangkan n. vestibularis inferior berada di kuadran posteroinferior dan juga inferior dari n. vestibularis superior sera posterior dari n. Koklearis. Arteri serebellaris anteroinferior merupakan vaskularisasi utama CPA juga sebagai sumber dari arteri labirintine. Arteri labirintine melalui IAC adalah end artery bagi organ-organ pendengaran dan keseimbangan. Arteri serebellaris anteroinferior memiliki hubungan variabel dengan nervus kranialis VII dan VIII serta IAC. ${ }^{4}$

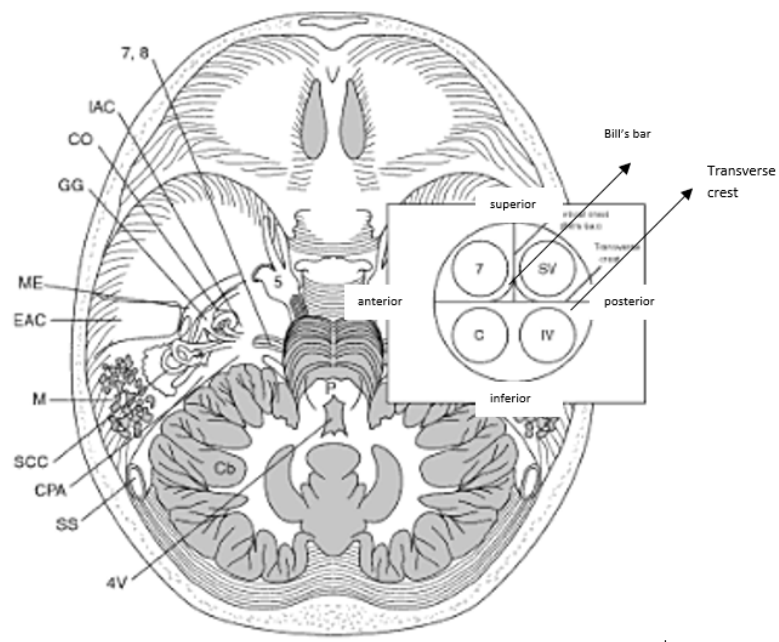

Gambar 2. Anatomi CPA dan hubungannya dengan tulang temporal didalam tengkorak. Pada inset dapat dilihat lokasi dari nervus kranialis diantara IAC: n.fasialis (7) dan n. koklearis (C) terletak di anterior, sedangkan $\mathrm{n}$. vestibularis superior dan inferior (SV dan IV) ada di setelah bagian posterior IAC. 5, n.trigeminus; 7, n.fasialis; 8, n.koklearis; IAC, internal auditory canal; CO, cochlea; GG, geniculate ganglion; $\mathrm{ME}$, middle ear; EAC, external auditory canal; $\mathrm{M}$, mastoid; SCC, semicircular canal; CPA, cerebellopontine angle; SS, sigmoid sinus; $4 \mathrm{~V}, 4^{\text {th }}$ ventricle; $\mathrm{Cb}$, cerebellum; P, pons. ${ }^{4}$ 


\subsection{Definisi Tumor CPA}

Tumor CPA adalah tumor yang mengenai daerah sudut serebelopontin. CPA merupakan suatu daerah berbentuk segitiga pada fossa posterior yang dibatasi oleh tulang temporal, serebellum dan pons. Pada bagian atas dan bawah dari CPA melintas beberapa nervus kranialis yaitu n.V,n.VII dan n.VIII yang kemudian menuju internal auditory Canal (IAC). ${ }^{4}$

\subsection{Etiologi Tumor CPA}

Penyebab dari tumor CPA belum sepenuhnya diketahui. Diduga erat tumor tersebut mempunyai kaitan dengan Neurofibromatosis tipe 2 (NF2) dan hal ini berkaitan dengan proses molekuler. Dari berbagai penelitian, adanya NF2 pada penderita tumor CPA menunjukkan berbagai variasi. Dari suatu penelitian, dari 33 kasus 61\% diantaranya mempunyai NF2. Sementara pada literatur lain, tumor yang sporadik terjadi mencapai 95\% dan 5\% sisanya berkaitan dengan NF2. Neurofibromatosis dapat terjadi dalam dua bentuk. Bentuk pertama biasanya melalui saraf seluruhb tubuh, terutama pada kulit dan tipe ke-2 menyebabkan tumor akustik pada kedua sisi. NF2 juga berkaitan dengan terjadinya meningioma dan sekitar 20\% dari penderita meningioma mempunyai bentuk dai neurofibromatosis. ${ }^{4}$

Etiologi tumor neuroma akustik merupakan defek pada kromosom 22 dan jarang sekali akan berubah menjadi maligna, akan tetapi jika tumor berkembang menjadi cukup besar sehingga dapat menekan batang otak yag akan membawa kematian. Neuroma akustik juga sering ditemui pada pasien neurofibromatosis 2, suatu defek gen pada kromosom 22, yang juga menimbulkan pembentukan tumor intraserebral lainnya. ${ }^{4}$

\subsection{Patofisiologi Tumor CPA ||||}

Salah satu tumor terbanyak di CPA adalah neuroma akustik atau vestibular Schwannoma. Neuroma akustik merupakan istilah tradisional, dimana sebenarnya tumor ini berasal dari divisi vestibularis dari saraf kranial kedelapan. Tumor ini muncul dari kanalis auditori internus yang berhubungan dengan anatomi saraf ke delapan dan produksi mielin. Pada waktu keluar dari batang otak, bagian proksimal saraf ke delapan secara histologis lebih 
mirip dengan jaringan saraf sentral. Mielin diproduksi oleh sel oligodendroglial di bagian distal, komposisinya lebih mirip dengan saraf perifer, dimana mielin diproduksi oleh sel Schwann. Zona transisi di antara mielin sentral dan perifer atau glial Schwannian junction dikenal dengan Obersteiner-Redlich zone. Secara tradisional dikatakan bahwa Vestibular Schwannoma berasal dari daerah ini kemungkinan karena tingginya densitas sel Schwann pada lokasi ini. Literatur terbaru menyatakan bahwa Vestibular Schwannoma muncul di bagian lateral dari zona tersebut dan bukan berasal dari sel Schwann pada zona transisi tersebut. $^{4}$

Penelitian terbaru telah meningkatkan pengetahuan molekular vestibular Schwannoma. Vestibular Schwannoma muncul sebagai hasil mutasi tumor supressor protein, merlin, berlokasi pada kromosom 22q12. Merlin adalah protein sitoskeletal dan dapat mengontrol proliferasi sel dengan mengatur perbanyakan, lokasi, dan pergantian cell-surface receptor. Terbentuknya Vestibular Schwannoma memerlukan mutasi dari penggandaan gen merlin. Fungsi gen merlin adalah untuk mencegah terbentuknya Vestibular Schwannoma. Mutasi somatik pada penggandaan gen merlin terdapat pada Vestibular Schwannoma yang sporadis. Sebaliknya, Vestibular Schwannoma familial muncul pada NF2 hanya membutuhkan satu kejadian mutasi somatik. Orang dengan NF2 memiliki satu gen merlin yang bermutasi dan satu gen merlin normal. Satu mutasi pada alel normal menyebabkan Vestibular Schwannoma bilateral pada umur 20 tahun. NF2 adalah bentuk utama dari neurofibromatosis, yang mengenai pasien yang memiliki tumor sistem saraf pusat, termasuk schwannoma, meningioma dan glioma. ${ }^{4}$

\subsection{Gejala Klinis}

Gejala yang terjadi pada tumor CPA sangat bervariasi tergantung dari ukuran, lokasi dan perkembangan dari tumor. ${ }^{2}$

- Gejala Auditoris

Kehilangan pendengaran yang asimetris atau unilateral merupakan gejala yang paling banyak terjadi pada Neuroma Akustik, mencapai 95\% dari seluruh penderita tumor jenis ini. Penderita akan mengeluh kehilangan pendengaran yang semakin lama semakin bertambah berat. Gejala lain yang sering didapati adalah tinnitus. Gejala ini sangat mungkin berkaitan dengan onset kehilangan pendengarannya, namun sering juga dijumpai timbulnya gejala tanpa keluhan kehilangan pendengaran. Biasanya penderita 
akan datang dengan keluhan adanya perasaan bising dengan nada tinggi secara terusmenerus. Tinitus biasanya terjadi ipsilateral dengan lokasi tumor. ${ }^{2}$

- Gejala Vestibular

Keluhan vertigo atau ilusi gangguan gerak, merupakan gejala lain yang sering didapati, mencapai 58\% dari seluruh penderita. Disequilibrium, perasaan seperti melayang atau tidak seimbang merupakan gejala yang banyak dikeluhkan. Terjadinya vertigo berkaitan dengan terjadinya penekanan pada nervus vestibuler atau terjadinya gangguan suplai darah pada sistem vestibular. Namun karena pertumbuhan tumor yang perlahan, vertigo yang terjadi pada penderita tumor CPA akan timbul secara lambat dan terkadang hal ini dapat dikompensasi oleh otak terhadap gangguan pada fungsi verstibular, sehingga penderita sering tidak mengeluhkannya. ${ }^{2}$

- Disfungsi Serebelar

Seiring dengan pertumbuhan tumor, ketika terjadi penekanan atau gangguan pada serebelum, maka dapat terjadi gejala-gejala gangguan serebelar, termasuk inkoordinasi, ataksia dan disequilibrium yang umumnya terjadi belakangan. Jika sudah mencapai tahap ini, maka gejala- gejala tersebut biasanya akan berkelanjutan dan terjadi terus-menerus. Inkoordinasi yang terjadi lebih berat dirasakan pada ektermitas bawah dibandingkan ekterimtas atas. Keadaan lain yang mungkin terjadi yaitu nistagmus, tremor dan hypotonia. ${ }^{3}$

- Gejala pada Nervus Kranialis

Nervus kranialis yang paling sering terganggu adalah nervus trigeminus. Facial bypesthesia atau parestesia dapat terjadi, kemudian kehilangan reflek kornea, dan seiring peningkatan pertumbuhan tumor, akan didapat gejala- gejala seperti kesemuatan dan mati rasa pada region wajah penderita. Jika tumor terus tumbuh membesar, bisa terjadi atropi pada otot-otot pengunyah. ${ }^{3}$

- Gejala Lain

Keadaan klinis lain yang bisa didapati yaitu nyeri kepala, hidrosefalus, gangguan saraf kranial bawah dan gangguan batang otak. Umumnya gejala-gejala ini terjadi jika lokasi tumor sudah keluar dari IAC. Nyeri kepala yang terjadi berkaitan dengan penekanan pada iritasi pada neural, vaskuler dan dura. Kemudian dapat obstruksi ventrikel IV dapat terjadi dan menghambat aliran cairan otak sehingga terjadi hidrosephalus; penderita bisa mengalami muntah, diplopia, perubahan status mental dan pada pemeriksaan funduskopi akan ditemukan papiledema. Gangguan pada nervus Glossopharyngeus dan vagus dapat menyebabkan suara serak, disfagia dan aspirasi. Penekanan pada nervus Hipoglossus kemudian menyebabkan disartria. ${ }^{3}$ 


\subsection{Pemeriksaan Radiologi ||l|| \\ 2.6.1 Computed Tomography (CT) scan}

CT-scan adalah peralatan radiodiagnostik dengan menggunakan sinar-x untuk menghasilkan gambaran tumor dengan penggunaan kontras. Disamping itu, keunggulan lainnya mampu memvisualisasikan dengan baik struktur anatomi tulang, mendeteksi erosi tulang, hiperostosis dan kalsifikasi. Selain itu, proses pengerjaan lebih murah, waktu lebih cepat, dan mudah dijangkau dibandingkan MRI. Selain memancarkan radiasi, kelemahan lainnya adalah sulit mendeteksi tumor yang berukuran kurang dari $1 \mathrm{~cm}$ dan adanya founsfield artefak (beam hardening) yang berasal dari tulang petrosus yang mengganggu hasil gambaran struktur disekitarnya. ${ }^{3}$

\subsubsection{Magnetic Resonance Imaging (MRI) | | || |}

MRI atau pencitraan resonansi magnetik adalah pemeriksaan yang memanfaatkan medan magnet dan energi gelombang radio untuk menampilkan gambar struktur dan organ dalam tubuh. Mesin MRI berbentuk seperti tabung yang dikelilingi oleh magnet melingkar yang besar. Dalam pemeriksaan MRI, pasien ditempatkan di tempat tidur yang kemudian dimasukkan ke lubang magnet. Medan magnet yang kuat akan terbentuk dan menyelaraskan proton atom hidrogen yang kemudian terkena pancaran gelombang radio. Hasilnya berupa sinyal yang dideteksi oleh bagian penerima pada mesin MRI. Komputer lalu memproses informasi penerima dan menghasilkan gambar Gambar dan resolusi dari MRI cukup detail dan dapat mendeteksi perubahan kecil pada struktur di dalam tubuh. Dalam beberapa prosedur, bahan kontras seperti gadolinium digunakan untuk meningkatkan akurasi gambar ${ }^{4}$

MRI diperlukan umumnya ketika teknik pencitraan lain tak bisa memberikan informasi yang memadai untuk penanganan kondisi pasien lebih lanjut yang mana belum terdiagnosis setelah menjalankan CT scan, ultrasonografi atau x-ray. MRI adalah salah satu teknik pencitraan diagnostik yang menunjukkan gangguan neurologis, penyakit otot, jaringan lunak, organ dan tulang. MRI adalah peralatan radiodiagnostik dengan menggunakan medan magnet yang merupakan gold standard dalam mendeteksi tumor CPA. Adapun kelebihan MRI dibandingkan dengan pemeriksaan CT Scan yaitu MRI lebih unggul untuk mendeteksi beberapa kelainan pada jaringan lunak seperti otak, sumsum tulang dan muskuloskeletal, mampu memberi gambaran detail anatomi dengan lebih jelas termasuk struktur neurovaskular, mampu melakukan pemeriksaan fungsional seperti pemeriksaan difusi, perfusi dan spektroskopi yang tidak dapat dilakukan dengan CT Scan, 
mampu membuat gambar ke dalam tiga potongan (axial, coronal dan sagital) tanpa merubah posisi pasien dan MRI tidak menggunakan radiasi pengion sehingga aman dilakukan pada wanita hamil. Namun kelemahannya adalah proses pengerjaan lebih mahal, waktu lebih lama dan tersedia pada fasilitas kesehatan yang lebih besar jika dibandingkan CT scan. Selain itu, tidak direkomendasikan pada pasien dengan claustrophobia dan pengguna alat pemacu jantung. ${ }^{4}$

Kualitas citra MRI ditentukan oleh intensitas sinyal yang dipancarkan oleh jaringan tubuh setelah masuk ke dalam medan magnet. Intensitas sinyal ditentukan oleh berbagai hal yaitu besarnya medan magnet, jumlah atom hidrogen yang ada pada jaringan, apabila jaringan mempunyai atom hidrogen yang banyak maka intensitas sinyal yang dikeluarkan juga kuat. Selain itu intensitas sinyal juga dipengaruhi oleh waktu relaksasi longitudinal T1, dan waktu relaksasi tranversal T2. Kekuatan medan magnet MRI yang biasa dipakai di klinik antara 0,3 sampai 1,5 Tesla. Sinyal yang dihasilkan merupakan tegangan yang tercatat ketika terjadi induksi dari medan magnet terhadap koil penerima. Kuat dan lemahnya magnetisasi akan berpengaruh pada kekuatan sinyal MRI dan berpengaruh pada intensitas gelap dan terang pada citra MRI. Bila signal MRI kuat maka akan memberikan citraan citra yang terang atau hiperintens, sedangkan apabila signal MRI lemah akan memberikan citra MRI gelap atau hipointens. Berikut ini terminologi yang dipakai untuk menyebutkan gambaran pada MRI:

- Intensitas sinyal

$\begin{array}{ll}\text { ○ } & \text { high signal intensity/bright } \\ \circ & \text { intermediate signal intensity } \\ \circ & \text { low signal intensity } \\ \circ & \text { very low signal intensity/dark }\end{array}$

- Perbandingan intensitas sinyal

- byperintense $=$ lebih terang

○ isointense = sama terang

- bypointense $=$ lebih gelap ${ }^{5}$

Berikut ini merupakan protokol sekuen MRI yang digunakan antara lain untuk menilai tumor di CPA antara lain:

- $T 1$ weighted terbentuk menggunakan waktu TE dan TR yang pendek. T1 weighted merupakan sekuen MRI untuk memperlihatkan gambaran anatomi termasuk soft tissue dibawah basis cranii. Adapun intensitas sinyal yang tampak, antara lain: very low 
signal intensity pada udara, kalsium, korteks tulang, dan darah aliran cepat; low signal intensity pada cairan serebrospinal, ligament, otot, tendon, kartilage; intermediate signal intensity pada jaringan tinggi protein (abses/kista kompleks); dan high signal intensity pada lemak, darah, kontras (gadolinium), melanin, dan protein.

- $\quad$ T2 weighted terbentuk menggunakan waktu TE dan TR yang lebih panjang. T2 weighted merupakan sekuen MRI untuk mengevaluasi kelainan anatomi, sisterna basalis, sistem ventrikel, ruang subdural, edema vasogenik dan flow void didalam vaskular. Adapun intensitas sinyal yang tampak, antara lain: very low signal intensity pada udara, kalsium, korteks tulang, dan darah aliran cepat; low signal intensity pada ligamen, tendon, kartilage; intermediate signal intensity pada lemak, otot, dan kartilage; dan high signal intensity pada cairan serebrospinal.

- $\quad$ T2* ultra thin slices (CISS, FIESTA, FFE) merupakan sekuen MRI untuk mengevaluasi nervus cranialis, IAC dan vascular.

- $\quad$ T1 post contrast merupakan sekuen MRI untuk menilai penyangatan kontras pada tumor setelah injeksi bahan kontras yang dilakukan.

- Fluid Attenuation Inversion Recovery (FLAIR merupakan sekuen MRI yang lebih sensitif untuk menilai lesi dengan menggunakan teknik menekan (suppression) sinyal $\mathrm{CSF} /$ water sehingga mampu membedakan sinyal CSF yang normal dengan lesi atau kelainan.

- Diffusion-Weighted Imaging (DWI), Apparent diffusion coefficient (ADC) merupakan sekuen MRI untuk mengevaluasi selularitas tumor yang berhubungan dengan difusi extracellular water. Restriksi difusi tampak jika high signal intensity pada DWI dan low signal intensity pada ADC, yang umumnya pada keadaan edema sitotoksik, abses/ inflamasi dan demielinisasi akut.

- Susceptibility Weighted Imaging (SWI) adalah sekuen pengembangan dari T2* GRE merupakan parameter untuk membedakan produk darah atau kalsifikasi didalam tumor. Sekuen ini memiliki magnitude image untuk mengevaluasi konten perdarahan dan phase image untuk menyevaluasi transformasi kalsifikasi.

- $\quad$ MR Angiography merupakan parameter untuk menilai struktur pembuluh darah, baik penyempitan, obstruksi dan kelainan dalam pembuluh darah.

- $\quad$ MR Perfusion merupakan parameter untuk menilai aliran darah orak relative dan volume 
yang berhubungan dengan tumor high-grade dan mengevaluasi pseudoprogresivitas and pseudorespons dari tumor.

- Spectroscopy: single atau multivoxel spectroscopy untuk mengukur metabolisme dari beberapa komponen biokimia dalam otak, seperti choline, creatine, lactate, $N$-acetylaspartate, alanine, lipids dan myoinositol. - $^{-5}$

\subsection{Jenis - Jenis Tumor CPA||||}

Untuk mempermudah seluruh spektrum tumor yang berpotensi ditemukan di CPA, dapat digunakan sebuah algoritma diagnostik berdasarkan lokasi asal, bentuk dan margin, kepadatan, intensitas sinyal dan penyangatan kontras. ${ }^{4}$ Dimulai dengan pendekatan pada hasil pertanyaan sederhana yaitu: "Apakah tumor mengalami penyangatan setelah pemberian kontras?" Jika jawabannya "Ya", maka akan ditentukan tempat asal tumor tersebut, yang mengarah pada tiga jenis yang berbeda berdasarkan apakah massa berasal dari sisterna CPA itu sendiri, cerebellum atau brain stem, atau basis cranii. Jika jawabannya tidak, maka intensitas sinyal pada T1WI sangat penting: sinyal ini mengarah ke lesi kistik jika tampak hipointens, atau lesi dengan komponen lemak atau kandungan protein jika hiperintens. Berdasarkan semua karakteristik pencitraan khusus yang ditampilkan oleh tumor yang berpotensi ditemukan pada CPA, maka diusulkan algoritma ringkas untuk memudahkan diagnosis (Gambar 3). ${ }^{4}$ 


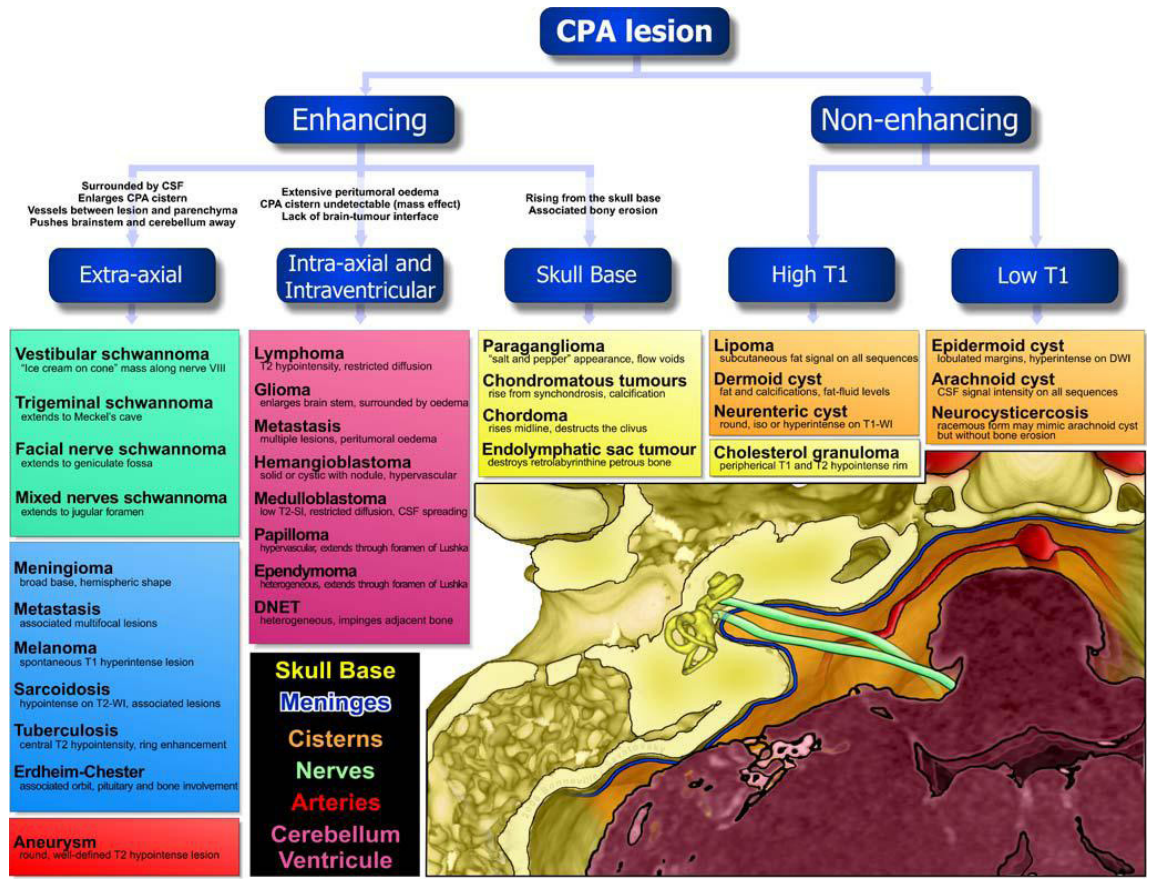

Gambar 3. Alogaritma pendekatan untuk diagnosis tumor CPA berdasarkan karakteristik khas, asal tumor dan penyangatan kontras. ${ }^{4}$

\subsubsection{Tumor yang Enhance ||I||}

\subsubsection{Tumor ekstra-aksial yang berasal dari CPA}

Lesi ekstra-aksial secara teoritis mudah dikenali di CPA: merela terpisah dari parenkim otak oleh celah cairan serebrospinal dan dapat memperbesar sisterna CPA. Mereka juga dapat mendorong saraf kranial, brain stem atau aspek anterior dari cerebellum. Bila tampak pembuluh darah di antara tumor dan parenkim otak, maka hal tersebut merupakan tanda lain dari asal lesi ekstra-aksial. Lesi tersebut termasuk schwannomas dan spektrum luas dari lesi massa meningeal, serta lesi vaskular. ${ }^{5}$ 


\section{a. Vestibular Schwannoma}

Vestibular schwannoma (sebelumnya disebut neuroma akustik) sejauh ini merupakan tumor yang paling sering di CPA, yang meliputi 70\% hingga 80\% dari semua tumor CPA. Kebanyakan vestibular schwannoma berkembang dari selubung Schwann dari saraf vestibular inferior di IAC di mana mereka tumbuh perlahan. Kemudian, tumor ini dengan halus mengikis tepi posterior porus acusticus dan dapat menimbulkan komponen bulat atau oval di CPA cistern, sehingga memberikan gambaran dengan pola yang khas seperti "ice cream cone". Pada CT, schwannoma biasanya isodense dan mengalami enhancement setelah pemberian kontras. Pada MRI, mereka menunjukkan isointensitas T1 dan intensitas sinyal tinggi T2, tetapi muncul sebagai defek pengisian hipointens pada T2-weighted MR cisternography resolusi tinggi, dan mengalami enhancement yang kuat setelah injeksi gadolinium. Enhancement pada meningen yang berdekatan mungkin terjadi pada vestibular schwannoma dan tidak spesifik untuk meningioma. Terdapat tiga tampilan MRI yang berbeda dari enbancement tumor yang dijelaskan dalam vestibular schwannomas: homogen (50-60\%), heterogen (30-40\%), dan kistik (5-15\%). Ukuran vestibular schwannomas berkorelasi dengan munculnya sinyal dan serapan gadolinium, dan subtipe Antoni histologis: vestibular schwannomas yang berukuran kecil biasanya homogen dan secara histologis terdiri dari pola Antoni tipe A, sedangkan vestibular schwannomas heterogen dan kistik lebih besar dan terdiri dari Antoni Pola B atau campuran tipe A dan B. Patut dicatat bahwa vestibular schwannoma selalu menjadi heterogen pada lesi yang lebih besar dari $25 \mathrm{~mm}$ karena terjadinya komponen kistik atau nekrotik tambahan (Gambar 3). Selain schwannomas IAC-CPA klasik, dapat juga ditemukan schwannomas kecil murni intrakanalikular, tetapi mungkin juga hadir dengan ekstensi dumbbell di koklea atau vestibula. Sebaliknya, vestibular schwannomas murni intracisternal, secara eksklusif terletak di CPA tanpa keterlibatan IAC, mewakili entitas yang berbeda karena mereka memiliki ruang besar untuk tumbuh sebelum menimbulkan gejala, sehingga biasanya lebih mengarah ke serebelum, batang otak atau kompresi ventrikel keempat daripada gangguan pendengaran, dan pada pencitraan selalu tampak besar, heterogen dan dapat menunjukkan hipervaskularisasi dengan kemungkinan pembuluh darah aliran tinggi. Diagnosis banding dengan lesi CPA lainnya tidak selalu sederhana dan teknik lanjutan diperlukan untuk dapat memecahkan kasus yang sulit. Pada urutan 3D fast spin-echo heavily T2-weighted, fokus kecil intensitas sinyal T2 tinggi yang diamati di batang otak dorsal di sisi yang sama dari tumor CPA dianggap hasil dari degenerasi nukleus vestibular yang terkait dengan vestibular schwannoma dan karena itu mungkin dapat mengarahkan diagnosis (Gambar 4). DWI menunjukkan komponen padat vestibular schwannomas biasanya isointense terhadap 
parenkim normal, dengan nilai apparent diffusion coefficient (ADC) mulai dari 1,1 hingga $1,7 \times 10^{-3} \mathrm{~mm}^{2} / \mathrm{s}$ dalam literatur dan peningkatan nilai ADC rata-rata dibandingkan dengan otak normal (1,4 x $10^{-3} \mathrm{~mm}^{2} / \mathrm{s}$ ) (Tabel 1). Telah diketahui bahwa ADC yang lebih tinggi mungkin mencerminkan kepadatan sel yang lebih rendah dari schwannoma Antoni tipe B. Namun, meskipun nilai rata-rata ADC secara signifikan lebih tinggi daripada meningioma, ada banyak tumpang tindih di antara mereka, sehingga DWI tidak dapat membedakan kedua jenis ini dengan baik. Di sisi lain, volume darah tumor relatif biasanya dinyatakan sebagai volume darah otak relatif ( $\mathrm{rCBV}$ ) dalam literatur, bahkan untuk lesi ekstra-aksial yang dievaluasi dengan perfusion imaging secara signifikan lebih rendah pada vestibular schwannomas daripada meningioma. Bahkan jika ada tumpang tindih antara rasio $\mathrm{rCBV}$ dari kedua jenis (rasio $\mathrm{rCBV}=\mathrm{rCBV}$ lesi/rCBV normal white-matter kontralateral), ambang 4,4 adalah rasio rCBV tertinggi yang dilaporkan pada schwannoma, sedangkan rasio rCBV rata-rata dari meningioma tipikal berkisar antara 6 hingga 9.5-7

Proton MR spectroscopy jarang dilaporkan dalam pemeriksaan lesi CPA, tentu saja karena seringnya kontaminasi lipid dalam spektrum lesi ekstra-aksial yang berbatasan dengan batas lemak tulang fossa posterior. Namun, tampaknya menarik bila mungkin dilakukan pada lesi besar, karena dapat membantu dalam membedakan schwannomas dari meningioma dengan menggambarkan puncak myo-inositol yang menonjol pada schwannomas pada 3,55 ppm (Gambar 3), sedangkan alanin yang ditemukan pada meningioma tidak ada pada schwannomas. ${ }^{5-7}$
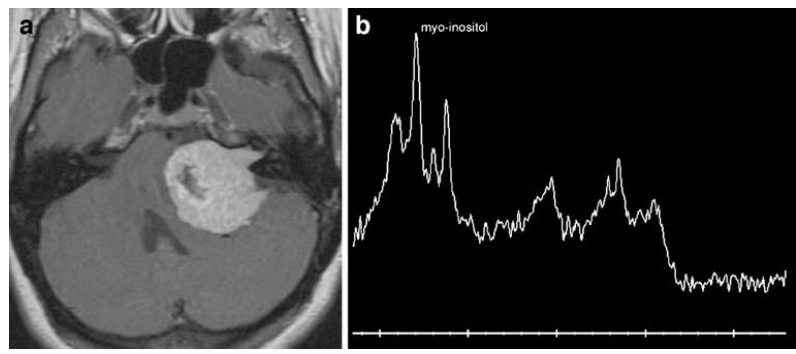

Gambar 4. Schwannoma vestibular besar pada wanita 53 tahun yang datang dengan keluhan pusing, tuli kiri dan sakit kepala berkepanjangan. a. Gambar Contrast-axial T1weighted menunjukkan gambaran lesi tipikal "ice cream cone" massa CPA kiri yang mengalami enhancement secara heterogen. Komponen yang memperbesar porus dari kanalis auditorius interna sangat mendukung diagnosis. b. Gambar MR spectroscopy memperlihatkan puncak myoinositol yang menonjol, ciri khas lain dari schwannomas. ${ }^{7}$ 


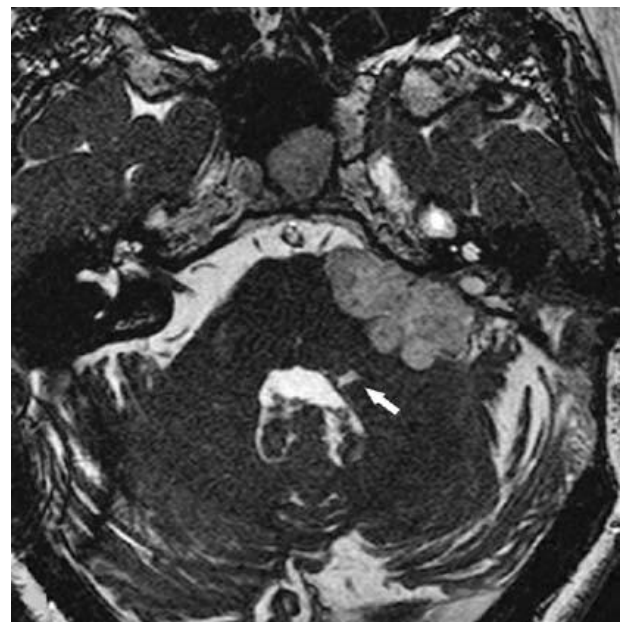

Gambar 5. Sisa pasca terapi dari vestibular schwannoma besar pada wanita berusia 44 tahun. Gambar heavily T2-weighted infra-milimetri aksial menggambarkan fokus intensitas sinyal tinggi di batang otak dorsal (panah), di sisi yang sama dari tumor CPA, yang diduga akibat degenerasi nukleus vestibular. ${ }^{7}$

\begin{tabular}{|l|l|l|l|l|}
\hline $\begin{array}{l}\text { Lesi eks- } \\
\text { tra-aksial }\end{array}$ & DWI & $\begin{array}{l}\text { Rata-rata ADC } \\
\text { (min-maks) }\end{array}$ & $\begin{array}{l}\text { Rasio rCBV } \\
\text { rata-rata (min- } \\
\text { maks) }\end{array}$ & Spektroskopi \\
\hline & & & & $3(2.2-4.4)$ \\
\hline Schwannoma & isointens & $1.4(1.1-1.7)$ & $8(3-18)$ & Myo-Inositol \\
\hline meningioma & Variabel* & $1(0,7-2.6)$ & $5(1.3-15)$ & $\begin{array}{l}\text { Lipid dan } \\
\text { kolin }\end{array}$ \\
\hline Tuberkustasis & $\begin{array}{l}\text { Hypo- to iso- } \\
\text { intense (jarang } \\
\text { hiperintens) }\end{array}$ & $1,1(0,8-1.5)$ & $<1$ & Lipid \\
\hline
\end{tabular}

Tabel 1 Ringkasan temuan difusi, perfusi, dan MR spectroscopy yang biasanya diamati pada enhancement ekstra-aksial yang paling sering pada lesi CPA. ${ }^{7}$

Catatan: DWI: intensitas sinyal pada diffusion-weighted imaging; ADC: apparent diffusion coefficient, nilainya $\times 10^{-3} \mathrm{~mm}^{2} / \mathrm{s}$; rasio $\mathrm{rCBV}$ : rasio volume darah otak relatif dari lesi ke otak normal; spektroskopi: puncak metabolit khas yang ditemukan pada MR spectroscopy. *Variabel: untuk lesi ini, intensitas sinyal pada DWI sangat bervariasi dari hipo- hingga hiperintens tanpa adanya pola yang mendominasi. 
Setelah diagnosis dibuat, MRI dapat digunakan untuk mengoptimalkan perencanaan perawatan berdasarkan temuan lesi: (i) ukuran tumor, yang dinilai paling dapat direproduksi pada irisan aksial resolusi tinggi dengan mengukur dua diameter terbesar. bagian ektrakanalikularis dari tumor, sejajar dan tegak lurus dengan permukaan posterior tulang temporal petrosa; (ii) jarak antara ekstremitas lateral bagian intrakanalikularis tumor dan fundus karena mempengaruhi prognosis pendengaran dan dapat mengubah pendekatan pembedahan. Hal ini lebih baik ditunjukkan dengan heavily T2-weighted MR cisternography karena jelas menggambarkan lesi sebagai hipointens dalam sinyal tinggi pada CSF; (iii) intensitas sinyal intralabirin: intensitas sinyal labirin normal hiperintens pada gambar 3D fast spin-echo T2-weighted dan ditekan pada urutan fluid attenuated inversion recovery (FLAIR), prognosis pendengaran yang buruk dapat diprediksi oleh intensitas sinyal T2 yang rendah pada isi labirin dibandingkan dengan telinga yang tidak terpengaruh, yang mungkin sesuai dengan intensitas sinyal yang ditekan lemah pada urutan FLAIR; (iv) identifikasi saraf wajah dan posisinya relatif terhadap vestibular schwannoma. Hal ini kadang-kadang ditunjukkan dengan penggunaan urutan heavily 3D T2-weighed, tetapi hampir pasti digambarkan lebih baik dengan pemberian bahan kontras yang memperkuat perbedaan intensitas sinyal antara lesi dan saraf wajah. ${ }^{8}$

\section{b. Schwannoma Saraf Kranial Lainnya}

Non-vestibular schwannoma jarang ditemukan di CPA. Jika intensitas sinyal dan perilaku pasca-kontras serupa dengan vestibular schwannoma, lesi non-vestibular schwannoma akan mudah dibedakan dari vestibular schwannoma karena mereka hadir dengan gejala, lokasi neuroanatomik, bentuk dan hubungan dengan foramen dan kanal basis cranii yang berbeda. Schwannoma trigeminal adalah lesi yang paling sering di antara nonvestibular schwannoma. Terletak cephalad ke vestibular schwannoma, memiliki arah anterior-posterior di CPA cistern dan dapat meluas ke Meckel's cave dan di sepanjang cabang trigeminal. Schwannoma nervus fasialis yang melibatkan CPA/ IAC mungkin sulit dibedakan dari schwannoma vestibular karena lokasi anatomis dan presentasi klinisnya yang serupa. Namun, mereka biasanya memiliki bentuk dumbbell dengan ekstensi sepanjang segmen saraf yang berbeda ke tulang temporal, serta massa bulat terkait yang mengarah ke fossa kranial tengah karena komponen yang berkembang di fossa genikulatum (Gambar 6). Schwannomas saraf aksesori glossopharyngeal, vagus dan spinal, juga disebut schwannoma foramen jugularis, dapat meluas ke kranial 
dengan komponen besar yang muncul kembali di CPA, terutama ketika kistik, dan meniru intracisternal vestibular schwannoma (Gambar 7). Namun, pusat yang lebih ke kaudal dan ekstensi melalui foramen jugularis yang membesar adalah fitur kunci dari diagnosis. ${ }^{8}$
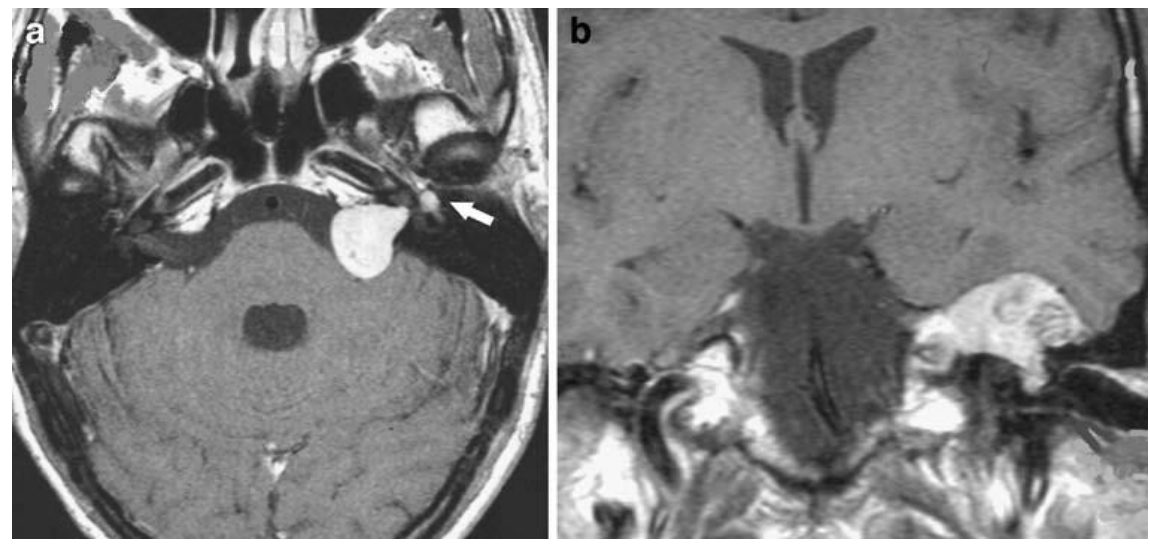

Gambar 6. Schwannoma saraf wajah kiri pada pria 47 tahun dengan kelumpuhan wajah kiri, gangguan pendengaran sensorineural dan tinnitus. a. Gambar dengan contrast-enhanced axial T1-weighted menunjukkan massa CPA yang meniru schwannoma vestibular, kecuali untuk komponen enhancement intralabirin

(tanda panah). b. Gambar contrast-enhanced coronal T1-weighted menunjukkan komponen tumoral intratemporal yang besar, terletak di fossa genikulatum, fitur yang menunjukkan schwannoma wajah. ${ }^{8}$
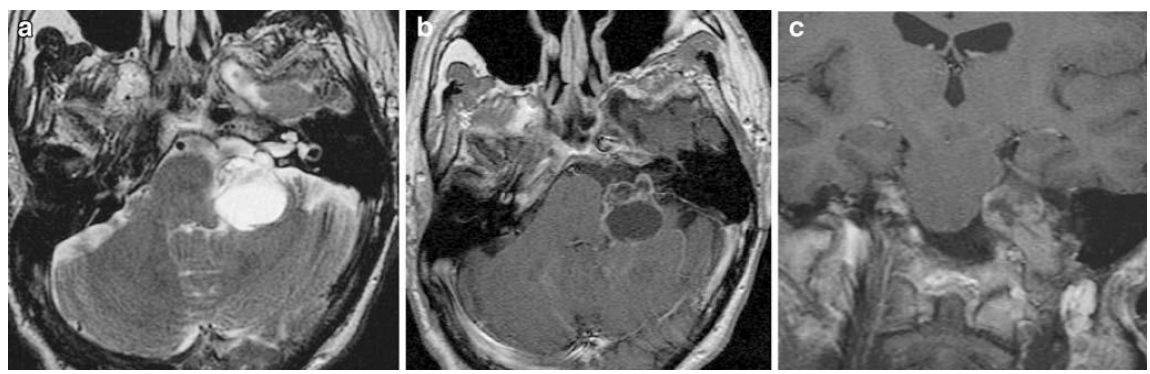

Gambar 7. Schwannoma foramen jugularis pada wanita berusia 38 tahun. a. Gambar dengan axial T2-weighted dan (b) gadolinium-enhanced axial T1-weighted menunjukkan lesi kistik yang terletak persis di depan IAC. c. Contrast-enhanced coronal T1-weighted menunjukkan luasnya schwannoma sepanjang perjalanan saraf campuran, menuju foramen jugularis. ${ }^{8}$ 


\section{Meningioma}

Meningioma adalah tumor ekstra-aksial intrakranial yang paling umum pada orang dewasa, tetapi merupakan lesi paling sering kedua di CPA setelah vestibular schwannoma, mewakili 10\%-15\% dari semua tumor di lokasi ini. Meningioma muncul dari sel meningotel arachnoid dan tumbuh perlahan di CPA, terlepas dari kanalis auditorius internal. Meningioma biasanya terletak di aspek posterior tulang temporal atau di daerah premeatal, darisana mereka dapat dengan mudah meluas ke IAC, tetapi tanpa memperbesar porus (Gambar 7). Pada CT, meningioma hiperdens pada 70\% kasus, terkalsifikasi pada sekitar 20\% dan menunjukkan reaksi tulang yang berdekatan termasuk hiperostosis dan enostotic spur. MRI dengan jelas menggambarkan lesi dural hemispheric atau oval berbasis luas, melekat pada dura mater petrosa atau aspek inferior tentorium. Meningioma biasanya isointense dengan korteks pada semua urutan, dan mengalami enhancement yang signifikan setelah injeksi kontras, seringkali homogen. Meskipun tidak spesifik untuk meningioma, enhancement intens pada dura peritumoral non-neoplastik yang menebal, yang disebut "tanda ekor dural", sangat sering berhubungan dengan meningioma dan dapat mengarahkan diagnosis bila diamati. Tanda ini, dan gambaran MRI konvensional lainnya, mungkin terlihat sangat mirip dalam berbagai macam lesi tumor dural di CPA, termasuk subtipe yang berbeda dari meningioma (meningioma meningotelial, fibrosa, transisi, atipikal, anaplastik atau sel jernih), tumor fibrosa soliter, limfoma atau metastasis, membuat diferensiasi pra operasi sulit. Nilai DWI masih dipertanyakan dalam diagnosis banding dan derajat patologis meningioma, tetapi tampaknya meningioma atipikal atau ganas cenderung memiliki ADC yang lebih rendah daripada yang jinak. Di sisi lain, limfoma juga memiliki ADC yang rendah. Seperti disebutkan sebelumnya, dynamic contrast-enhanced perfusion MRI menemukan rasio rCBV rata-rata yang sangat tinggi pada meningioma, mulai dari 6 hingga 9, dengan rasio rCBV yang bahkan lebih tinggi pada meningioma atipikal (Tabel 1). Menariknya, ini secara signifikan lebih tinggi daripada pada schwannoma (ratarata $\mathrm{rCBV}$ ratio=3) atau pada limfoma (rata-rata $\mathrm{rCBV}$ ratio=1), sehingga memberikan karakteristik lain yang menjelaskan perbedaan antara lesi CPA ini. Pada proton MR spectroscopy, kombinasi peningkatan glutamat/glutamin dan adanya karakteristik alanin 1,5 ppm dianggap sangat spesifik untuk meningioma (Gambar 8). Urutan T2-weighted resolusi tinggi tiga dimensi juga harus dilakukan pada meningioma CPA karena hasil bedah saraf tidak hanya bergantung pada konsistensi dan ukurannya, tetapi juga pada lokasi yang tepat dan hubungannya dengan struktur neurovaskular di sekitarnya. Demikian pula, sejauh mana keterlibatan IAC harus dinilai dengan urutan ini karena 
pembedahan meningioma di CPA yang melibatkan IAC membawa peningkatan tingkat morbiditas saraf kranial dan oleh karena itu memerlukan manajemen bedah khusus. ${ }^{7-9}$
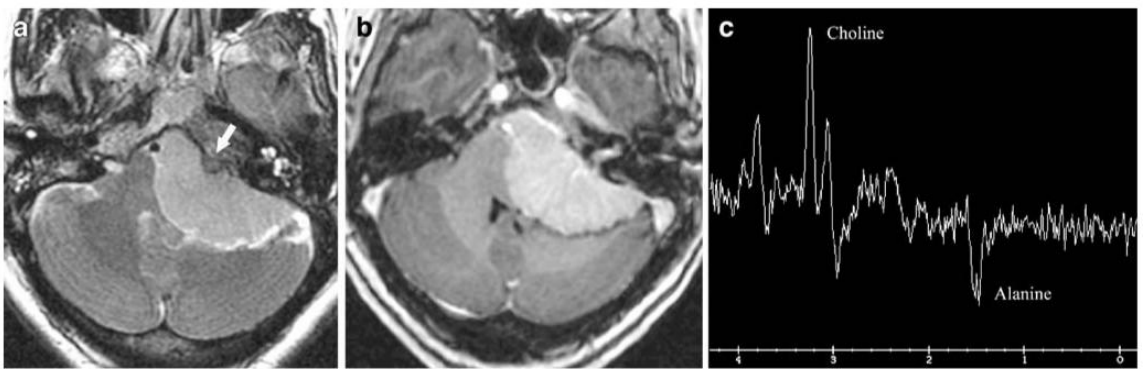

Gambar 8. Meningioma CPA kiri pada wanita 49 tahun dengan pusing dan gangguan pendengaran sensorineural kiri. a. Gambar axial T2-weighted menunjukkan massa hiperintens ekstra-aksial homogen yang menekan batang otak dan aspek anterior hemisfer serebelar kiri. Perhatikan enostotic spur di premeatal area (tanda panah), fitur yang mengarahkan ke meningioma. b. Contrast-enhanced axial gradient echo T1-weighted menunjukkan enhancement lesi yang intens bahkan dengan perluasan di dalam IAC.c. Proton MR spectroscopy, pada panjang TE $=135 \mathrm{~ms}$, menunjukkan adanya karakteristik alanin double negatif yang diamati pada $1,5 \mathrm{ppm}^{9}$

\section{d. Metastasis}

Metastasis meningeal dari kanker paru-paru atau payudara, melanoma dapat menyerang CPA. Jika metastasis CPA harus dicari ketika vertigo atau gejala saraf kranial lainnya muncul pada pasien kanker yang diketahui, diagnosis pra operasi yang benar seringkali sulit dilakukan pada pasien yang tumor primernya belum terdeteksi pada saat identifikasi lesi di CPA. Pada pencitraan, adanya lesi serebral multifokal sangat menunjukkan adanya metastasis (Gambar 9), tetapi metastasis CPA mungkin soliter dan meniru tumor jinak CPA, atau bilateral, meniru neurofibromatosis. Metastasis dari melanoma kulit tentu merupakan etiologi paling sering dari tumor melanositik di CPA. Namun, jumlah melanosit yang sedikit yang biasanya ada di meningen fossa posterior mungkin jarang menimbulkan tumor melanositik primer jinak atau ganas. Kista epidermoid yang terkait dengan sel melanositik maligna juga telah menjadi subjek laporan kasus tunggal tumor berpigmen yang tidak biasa di CPA. Diagnosis akhir biasanya dibuat dengan analisis patologis lesi dural menyerupai meningioma pada pencitraan pra operasi. Namun, sifat pigmentasi dari 
massa seperti meningioma ini dapat dicurigai jika menunjukkan intensitas sinyal tinggi T1 homogen intrinsik yang halus, karena efek paramagnetik dari melanin yang terkandung dalam tumor. Tapi kecuali untuk tumor melanositik, tidak ada karakteristik pencitraan yang patognomonik dari diagnosis metastasis, tetapi agresivitas yang tidak biasa dari tumor jinak lainnya yang muncul sebagai massa menyerupai schwannoma atau meningioma harus membuat ahli radiologi memikirkan kemungkinan metastasis dan memeriksa paru-paru dan payudara dengan hati-hati. Di sisi lain, perfussion MRI dapat memberikan informasi tambahan yang membantu dalam membedakan metastasis dural dari meningioma, dengan menunjukkan rasio rCBV biasanya cukup tinggi (sering antara 1,5 dan 5), yang mungkin mengarahkan diagnosis metastasis, sementara meningioma memiliki rasio rCBV yang lebih tinggi (sekitar 8), dan rCBV limfoma hampir sama dengan parenkim normal. Pada DWI, sebagian besar lesi metastasis nekrotik akan memiliki difusivitas tinggi dengan sinyal rendah dan nilai ADC tinggi. Pengecualian pada metastasis adenokarsinoma yang mungkin menyerupai abses dengan difusivitas terbatas dan sinyal DWI tinggi dan nilai ADC rendah. MR spectroscopy menunjukkan, peningkatan kolin dan puncak lipid yang dominan dalam metastasis, temuan penting lainnya yang dianggap mendukung diagnosis..$^{8-9}$

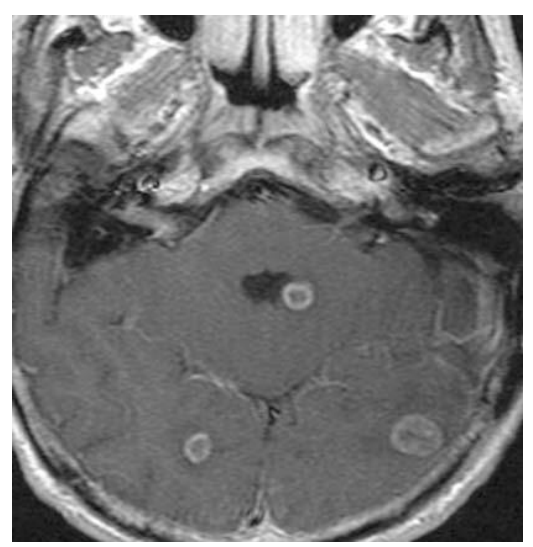

Gambar 9. Metastasis intra dan ekstra-aksial pada pria 69 tahun dengan kanker paru-paru dan sindrom hipertensi intrakranial. Gambar dengan contrast-enhanced axial

T1-weighted yang menunjukkan lesi IAC-CPA kanan yang mungkin menyerupai vestibular schwannoma kecil. Kombinasi dengan beberapa lesi intra-aksial menunjukkan metastasis. ${ }^{9}$ 


\section{Aneurisma}

Aneurisma vertebrobasilar dan dolichoectasia merupakan bagian penting dari lesi non-tumor CPA yang dapat menyebabkan kompresi saraf kranial atau batang otak. Di lokasi ini, dan bahkan di saluran pendengaran internal, aneurisma intrakranial dapat menyerupai vestibular schwannoma, terutama pada CT, karena tampak sebagai lesi bulat atau oval yang berbatas tegas yang mengalami enhancement secara intens setelah pemberian kontras. Pada MRI, aneurisma tanpa trombus internal yang signifikan memiliki rongga aliran yang jelas dan artefak pulsasi pada semua urutan spin echo, tetapi menunjukkan intensitas sinyal yang iso hingga tinggi dan pola variabel serapan gadolinium pada gambar T1-weighted ketika ada trombus intraluminal. Namun, diagnosis harus dicurigai secara sistematis ketika lesi bulat/ oval dengan intensitas sinyal rendah atau tanpa intensitas terlihat pada urutan T2-weighted (Gambar 10). MR Angiografi kemudian harus dilakukan untuk mengkonfirmasi diagnosis dan menggambarkan arteri induk, yang bisa saja merupakan arteri serebelar postero-inferior, arteri serebelar antero-inferior, arteri vertebralis atau arteri basilaris itu sendiri. ${ }^{9}$

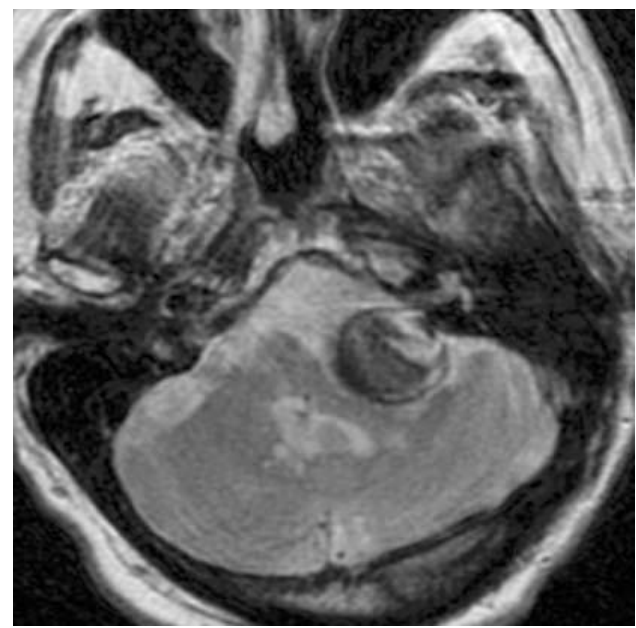

Gambar 10. Aneurisma vertebrobasilar besar dengan trombosis parsial pada pria 76 tahun dengan demensia vaskular. Gambar axial T2-weighted menunjukkan lesi hipointens bulat yang jelas, sangat sugestif terhadap aneurisma, yang kemudian dikonfirmasi oleh MR angiogram (tidak ditampilkan). ${ }^{9}$ 


\section{Kavernoma}

Malformasi kavernosa juga dapat ditemui di CPA. Bahkan jika kebanyakan kavernoma infratentorial terletak di pons, kavernoma serebelar intra-aksial superfisial atau bahkan ekstraaksial di CPA ada dan mungkin secara klinis dan radiologis meniru schwannoma vestibular. MRI secara akurat menegakkan diagnosis pada sebagian besar kasus kavernoma intraaksial: mereka muncul sebagai lesi yang berbatas tegas dengan inti retikulat dengan intensitas sinyal campuran pada gambar T1-weighted dan biasanya intensitas sinyal tinggi pada gambar T2-weighted, dikelilingi oleh tepi perifer hemosiderin yang menunjukkan hipointensitas pada semua urutan, dengan enhancement sedang hingga tidak ada setelah injeksi kontras (Gambar 11). Kavernoma CPA ekstra-aksial berbeda dan muncul dari saraf kranial. Sebagian besar kasus yang dilaporkan memiliki peningkatan sinyal intrinsik samar pada gambar T1-weighted, dengan peningkatan variabel setelah pemberian gadolinium, dan menunjukkan hiperintensitas T2 sentral yang lebih klasik dikelilingi oleh tepi intensitas sinyal rendah. Adanya lesi hipointens intraparenkim lain atau multipel yang dideteksi oleh gambar gradient echo T2 merupakan petunjuk yang mengarah ke diagnosis. ${ }^{9}$
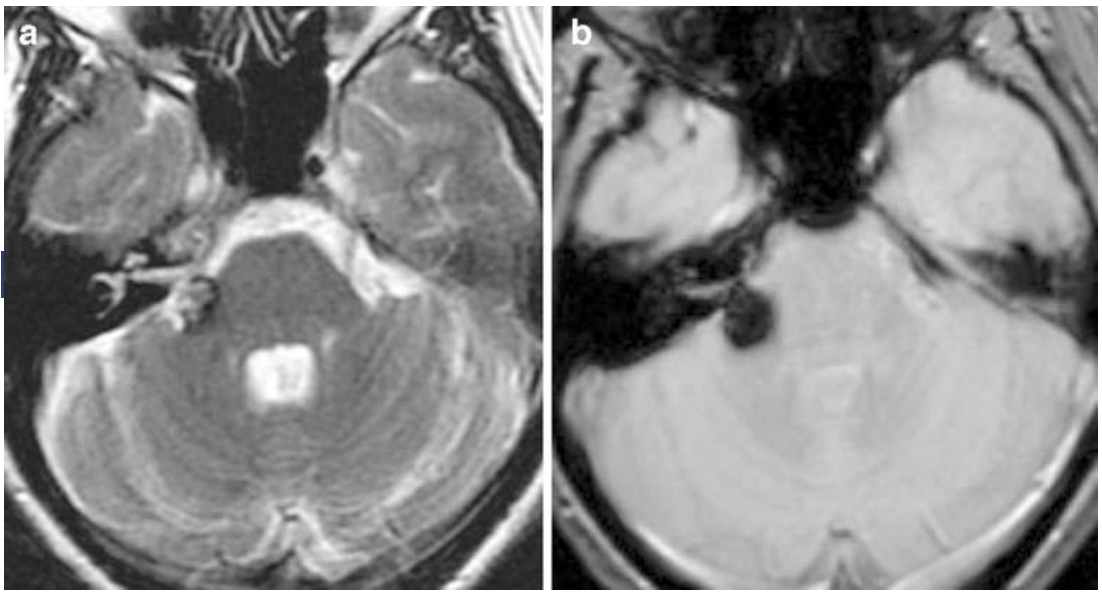

Gambar 11. Kavernoma CPA kanan pada wanita 42 tahun dengan sakit kepala. a. Gambar axial T2-weighted memperlihatkan gambaran lesi tipikal "popcorn" di depan IAC kanan, dengan inti hiperintens dikelilingi oleh tepi perifer dengan intensitas sinyal rendah. b.

Gradient echo T2-weighted pada tingkat yang sama menunjukkan sifat hemoragik dari lesi. ${ }^{9}$ 


\section{g. Sarkoidosis}

Sarkoidosis melibatkan sistem saraf pada sekitar 5\% kasus dan biasanya bermanifestasi sebagai inflamasi granulomatosa pada meningen dan regio hipotalamus. Lesi meningeal muncul dalam pola seperti plak difus, tetapi massa berbasis dural fokal yang biasanya jarang juga terkadang ditemukan di CPA. Diagnosis tergolong sulit, tetapi dapat dipertimbangkan karena granuloma sarkoidosis yang byperattenuating di CT, isointense pada gambar T1-weighted, sangat enhanced setelah injeksi media kontras dan secara keseluruhan menunjukkan intensitas sinyal rendah homogen sugestif pada gambar T2-weighted. ${ }^{9}$
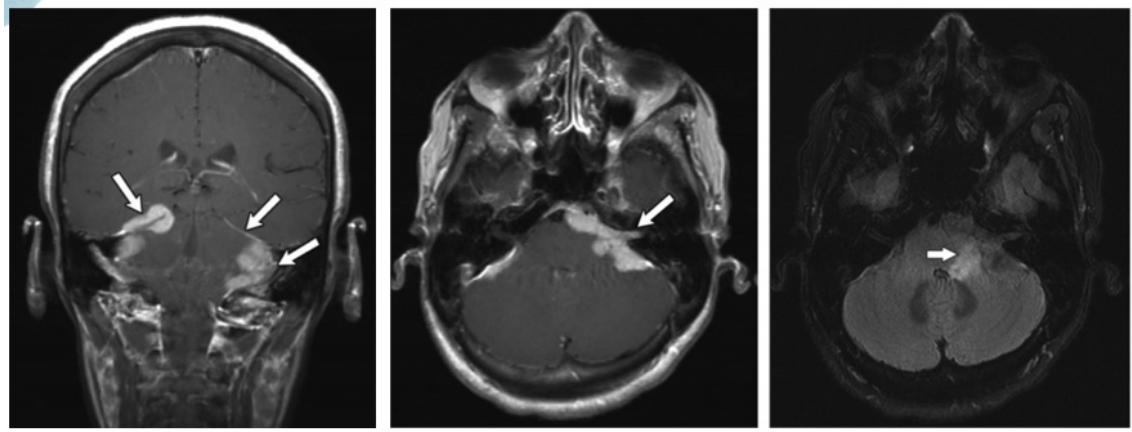

Gambar 12. Sarkoidosis pada wanita 53 tahun. Gambar a. Coronal T1+C tampak penyangatan nodular pachymeningeal (panah) di dura basilar, CPA dan tentorium, b. axial T1+C tampak Penyangatan nodular pada kompleks CN VII \&VIII (panah), dan c. axial FLAIR tampak lesi hiperintens di medulla kiri (lesi parenkimal). ${ }^{9}$

\section{h. Tuberkulosis $\|$}

Tuberkulosis sistem saraf pusat biasanya bermanifestasi sebagai meningitis basilar tuberkulosis yang mungkin berhubungan dengan tuberkuloma intra-aksial atau abses tuberkulosis. Tuberkuloma soliter yang muncul sebagai massa ekstra-aksial yang menyerupai meningioma, merupakan keadaan klasik namun jarang yang bahkan lebih jarang terjadi pada CPA. Tuberkuloma intraparenkim superfisial, yang lebih sering, mungkin sulit dibedakan dari lesi ekstra-aksial, dan tingkat kecurigaan yang tinggi untuk tuberkulosis harus dipertahankan ketika dihadapkan dengan massa CPA dengan adanya faktor risiko tuberkulosis. Temuan CT dan MRI bervariasi tergantung pada stadium 
penyakit dan karakter lesi (yaitu, non-caseating, caseating dengan pusat padat atau caseating dengan pusat nekrotik). Ini mungkin menjelaskan mengapa kasus tuberkuloma tanpa difusi terbatas dan ADC normal telah dilaporkan. Kasus caseating dengan pusat padat tampak sebagai lesi ring-enhancing, dengan hipointensitas T2 sentral yang paralel dengan intensitas sinyal tinggi pada gambar difusion-weighted dan kemungkinan ADC rendah. Kehadiran beberapa lesi bersamaan dengan pola DWI yang berbeda akhirnya dapat menjadi petunjuk untuk diagnosis lesi tuberkulosis (Gambar 13). MR spectoroscopy juga dapat membantu dalam mencapai diagnosis tuberkuloma: dalam laporan kasus lesi yang terletak di luar fossa posterior, membedakan tuberkuloma ekstra-aksial dari meningioma dilakukan dengan menggambarkan puncak lipid yang meningkat 0,9 dan 1,33 ppm dan temuan karakteristik tuberkulosis. Menariknya, puncak yang terdeteksi di inti lesi tuberkuloma dengan proton MR spectroscopy juga berbeda secara khas dari abses otak piogenik. Akhirnya, berbeda dengan tumor, lesi infeksius dan khususnya tuberkuloma menunjukkan hipoperfusi pada MR perfusion dengan rasio $\mathrm{rCBV}$ biasanya $<1$. $^{9}$
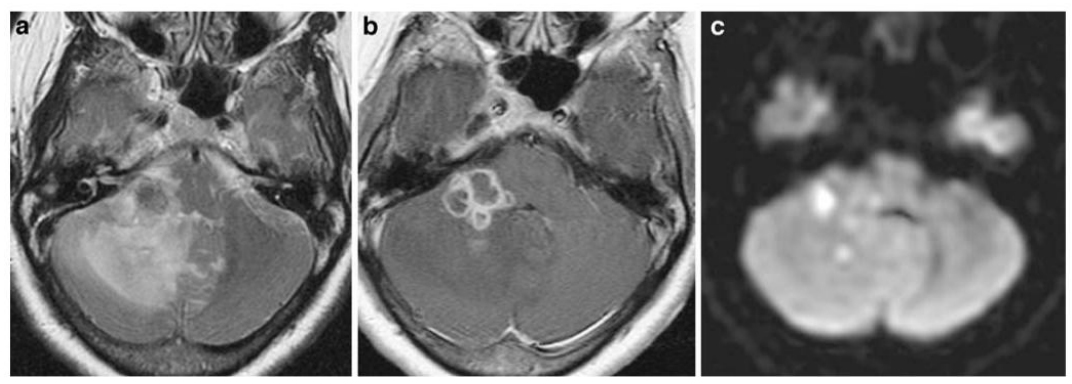

Gambar 13 Tuberkuloma pada wanita 31 tahun dengan meningitis dan sindrom serebelar

kanan. a. Gambar axial T2-weighted menunjukkan, di depan IAC kanan, beberapa lesi superfisial serebelar dengan campuran intensitas sinyal iso dan hyposignal. b. Gambar axial

T1-weighted yang mengalami enhancement dengan kontras menunjukkan peningkatan tepi periferal dari lesi yang terkumpul ini c. Tuberkuloma hadir dengan intensitas iso atau hypersignal pada diffusion weighted imaging, tetapi koefisien difusi yang tampak selalu dalam nilai normal, mirip dengan parenkim. ${ }^{9}$ 


\section{Erdheim-Chester Disease}

Erdheim-Chester Disease merupakan penyakit sistemik histiositosis non-Langerhans yang jarang ditemukan dengan etiologi yang tidak diketahui yang mempengaruhi beberapa sistem organ, dengan predileksi di tulang, bola mata dan otak. Keterlibatan otak disebabkan oleh pola infiltratif campuran (lesi yang menyebar luas, nodul atau massa intraserebral dari daerah dentata dan hipofisis) dan massa meningeal ekstra-aksial, dengan penebalan duramater atau tumor mirip meningioma. Diagnosis kelainan ekstra-aksial akan cukup sulit jika gangguan yang mendasarinya belum diidentifikasi, karena meningeal enhancing dural mass mungkin menyerupai meningioma. Namun, kombinasi lesi dural dengan massa intra-orbital dan hipofisis serta perubahan osteosklerotik tulang pada pasien dengan sindrom serebelar sangat mendukung diagnosis (Gambar 14). ${ }^{9}$
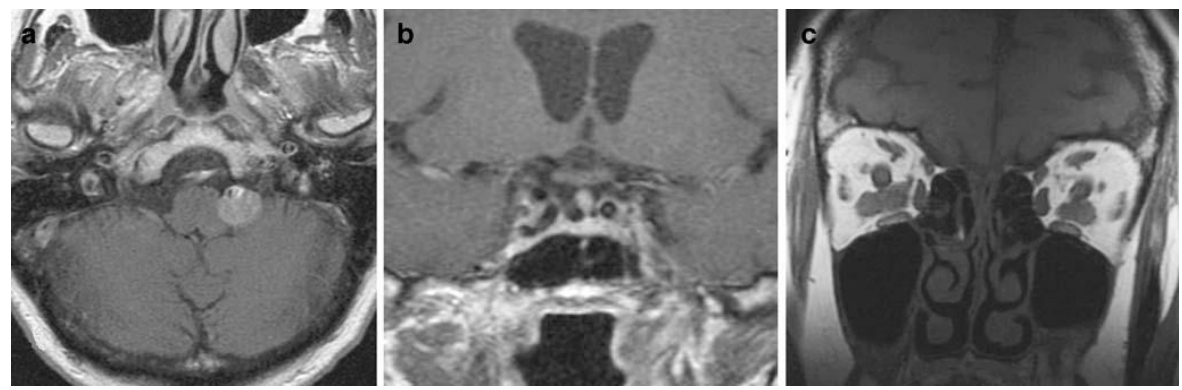

Gambar 14. Penyakit Erdheim-Chester pada pasien berusia 38 tahun dengan diabetes insipidus dan eksoftalmia. a. Gambar axial T1-weighted yang mengalami enhancement dengan kontras menunjukkan massa bulat ekstra-aksial di CPA kiri yang meningkat secara homogen. b. Coronal T1-weighted yang mengalami enhancement dengan kontras menunjukkan lesi yang mengalami enhancement di tangkai. c. Gambar coronal T1weighted menggambarkan lesi identik di kedua ruang intra-kerucut. Kombinasi lesi granulomatosa pada meningen, orbita dan area sellar sangat mendukung diagnosis. ${ }^{9}$

\subsubsection{Tumor intra-aksial dan intraventrikular}

Pada pencitraan, penanda anatomis yang tepat tidak selalu dapat secara tepat digambarkan di fossa posterior, dan lokasi lesi intra atau ekstra-aksial tidak selalu pasti, terutama ketika sisterna itu sendiri tidak lagi ditemukan pada gambar Edema peritumoral 
yang luas di sekitar lesi enhancing, dengan pusat pada efek massa yang signifikan yang melenyapkan CPA cistern sangat tidak mungkin ada pada tumor ekstra-aksial jinak. Dalam keadaan ini, tumor intra-aksial seperti limfoma, glioma atau metastasis harus dicurigai. ${ }^{10}$

\section{a. Limfoma}

Limfoma sistem saraf pusat primer dapat berupa intra atau ekstra-aksial di CPA. Namun, fitur pencitraan adalah identik untuk kedua situs asal, kecuali bila terdapat tandatanda yang menunjukkan lokasi. Pada pasien imunokompeten, limfoma muncul dengan gambaran intermediet atau hiperatenuasi pada CT dengan enhancement yang rata setelah pemberian kontras. Pada MRI, mereka muncul dengan intensitas sinyal menengah hingga rendah pada gambar T1-weighted yang secara kuat dan homogen meningkat setelah pemberian gadolinium, dan intensitas sinyal rendah T2 yang khas pada sekitar 75\% kasus. Intensitas sinyal rendah yang terakhir ini disebabkan oleh seluleritas yang tinggi dari tumor ini, yang juga menjelaskan intensitas sinyal yang tinggi dari limfoma yang biasanya diamati pada pencitraan diffusion-weighted imaging (DWI) dengan nilai apparent diffusion coefficient (ADC) yang rendah (Gambar 1). Karena kurangnya neoangiogenesis dan peningkatan permeabilitas sawar darah-otak yang diamati pada limfoma, tumor ini memiliki volume darah otak relatif (rCBV) yang agak rendah dibandingkan dengan tumor intra-aksial ganas lainnya. Memang, rasio rCBV mereka secara statistik lebih rendah (sekitar 1) dibandingkan metastasis atau glioma tingkat tinggi (sekitar 5), sehingga memberikan kriteria yang khas yang memungkinkan diferensiasi di antara lesi ini. ${ }^{11}$ 

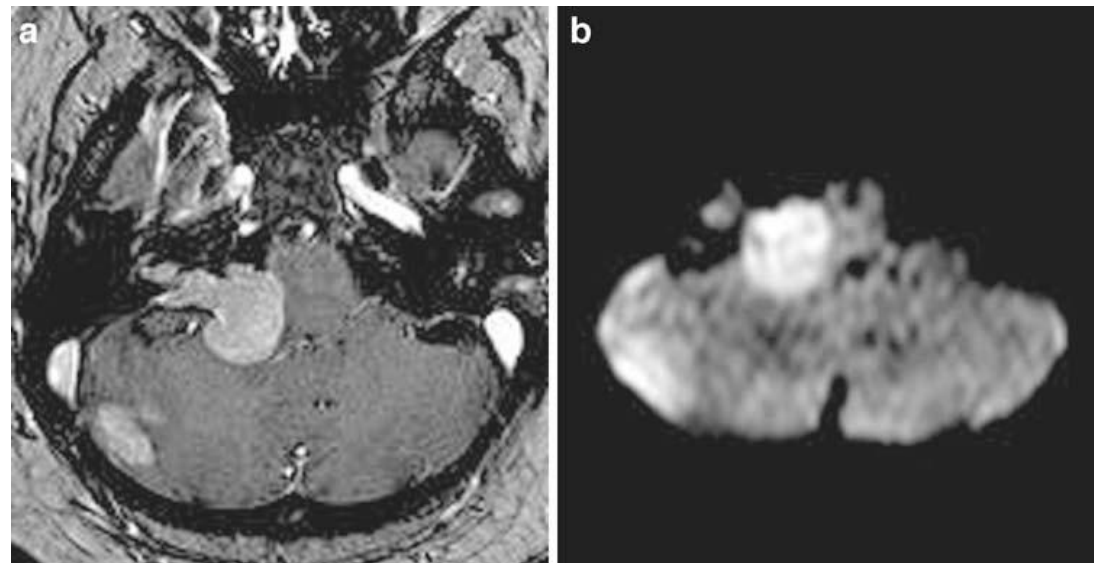

Gambar 15a, b Limfoma otak primer pada pria berusia 49 tahun. Sebuah

Gambar axial gadolinium-enhanced T1-weighted MR menunjukkan lesi CPA kanan yang mengalami enhancement secara homogen dengan bagian intracanalicular yang bisa meniru vestibular schwannoma, b. Pada gambar dengan diffusion-weighted image, tumor muncul dengan intensitas sinyal yang tinggi dan memiliki difusi yang terbatas dengan koefisien difusi yang tampak rendah (tidak ditampilkan), suatu gambaran yang menunjukkan limfoma. Perhatikan lesi serebelar kanan juga tampak pada gambar a. ${ }^{11}$

Pada individu yang immunocompromised, limfoma biasanya muncul sebagai lesi perifer multipel dengan edema peritumoral yang nyata. Namun, karena temuan tumpang tindih yang signifikan, limfoma tidak selalu dapat dibedakan secara jelas dari toksoplasmosis, diagnosis banding utama dalam situasi ini, berdasarkan temuan pencitraan pada urutan konvensional, serta pada DWI atau MR perfusi. ${ }^{11}$

\section{b. Glioma ||||}

Tumor glial batang otak, dan terutama astrositoma pilositik pada dewasa muda, dapat bermanifestasi sebagai perluasan batang otak asimetris yang jarang ditemukan bertangkai dan eksofitik, menginvasi CPA (Gambar 16) dan bahkan meniru vestibular schwannoma dengan memperbesar porus acusticus. Tumor ini tidak memiliki fitur pencitraan spesifik di lokasi ini: muncul dengan hiperintensitas T2, hipointensitas $\mathrm{T} 1$ dan peningkatan variabel tergantung pada derajat glioma. Glioma biasanya dikelilingi oleh edema yang berdekatan. 
Diffusion dan perfusion imaging dari bagian padat tumor glial juga bergantung pada derajat histologisnya. Secara umum, semakin rendah nilai ADC, semakin tinggi rCBV, semakin tinggi derajat tumornya. ${ }^{12}$
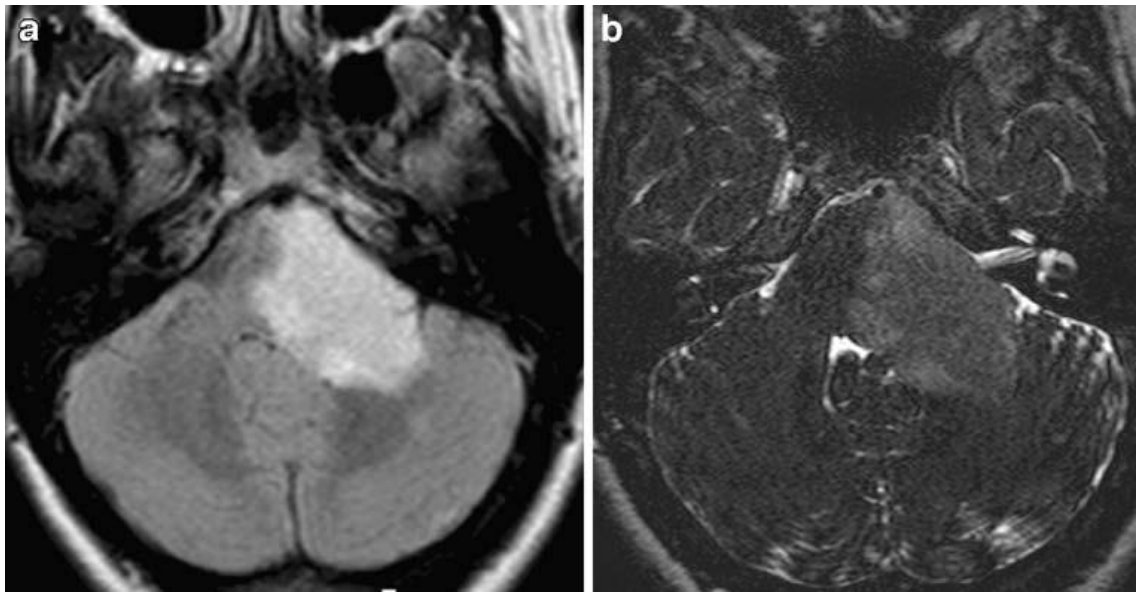

Gambar 16. a, b Glioma batang otak pada wanita 33 tahun dengan kelumpuhan wajah kiri progresif, gangguan pendengaran sensorik dan pusing. a. Gambar axial proton densityweighted menunjukkan lesi intensitas sinyal tinggi di CPA kiri. b Gambar axial inframilimetric heavily T2-weighted menunjukkan lokasi tumor intra-aksial dengan antarmuka tumor-parenkim samar dan tidak adanya komponen intrakanalicular. ${ }^{12}$

\section{c. Metastasis}

Metastasis intrakranial dapat terjadi di mana-mana.Metastasis mungkin terletak ekstraaksial dan meniru meningioma atau schwannoma di CPA, seperti yang dijelaskan sebelumnya secara rinci di bagian pertama ulasan ini, atau intra-aksial, persis terletak di depan IAC, sering dikelilingi oleh edema peritumoral (Gambar 17). Beberapa lesi atau riwayat kanker yang diketahui sebelumnya akan mengarah pada diagnosis. Selain itu, teknik MRI tingkat lanjut sangat membantu dan menunjukkan rasio $\mathrm{rCBV}$ rata-rata lebih rendah dari glioma derajat tinggi, dan nilai ADC yang lebih tinggi daripada bagian peningkatan glioma dan abses derajat tinggi. MR spectroscopy menunjukkan puncak yang dominan pada lipid dalam metastasis, hal ini merupakan temuan penting lainnya yang dianggap mendukung diagnosis. ${ }^{12}$ 

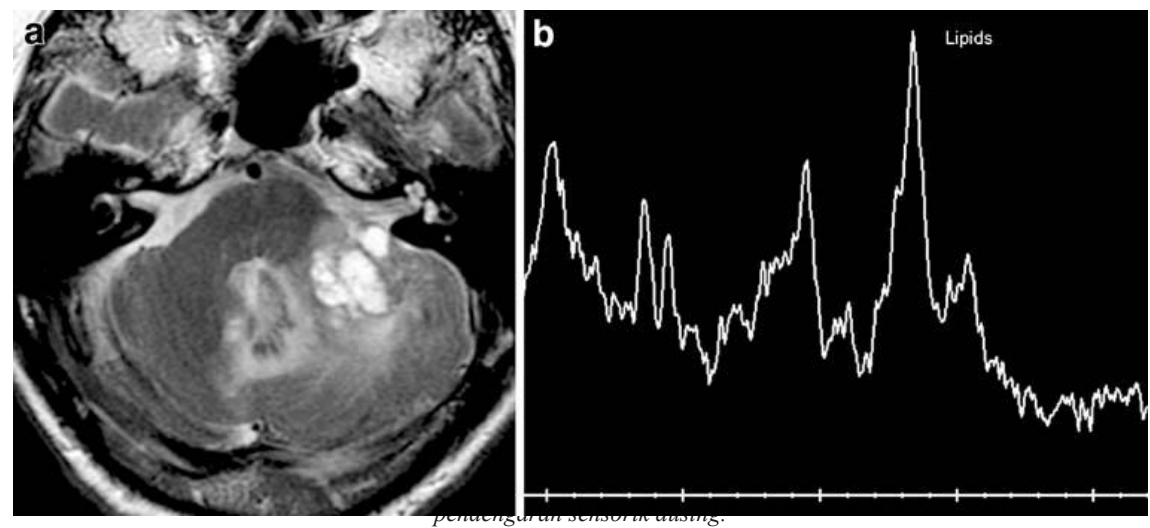

Gambar 17a, b Metastasis dari kanker usus besar pada pria 56 tahun dengan pusing dan sakit kepala. a. Gambar axial T2-weighted menunjukkan lesi kistik hiperintens di depan

IAC kiri. Edema peritumoral dan tidak ditemukannya pelebaran CPA cistern lebih mendukung lesi intra-aksial daripada lesi schwannoma. b TE MR spectroscopy pendek menunjukkan puncak dominan pada lipid, sebuah fitur yang menunjukkan metastasis. ${ }^{12}$

\section{d. Hemangioblastoma || $\mid$}

Hemangioblastoma adalah tumor intra-aksial vaskular jinak yang terletak di hemisfer serebelum, dengan kemungkinan meluas ke CPA. Hemangioblastoma sporadis di sebagian besar kasus tetapi merupakan manifestasi penyakit von Hipple-Lindau pada $25 \%$ kasus. Kelainan ini merupakan fakomatosis dominan autosomal yang menyebabkan multipel hemangioblastoma retina dan serebral, karsinoma sel ginjal, serta kista dan tumor pankreas. Hemangioblastoma biasanya muncul sebagai massa yang berbatas tegas dengan tepi rata, seluruhnya padat (40\%) atau kistik, dengan bipervascular enhancing mural nodul (60\%), edema disekitarnya biasanya tidak ada. Ketika kistik, komponen cair biasanya tampak hipointens pada gambar dengan T1-weighted dan hiperintens pada gambar T2weighted tetapi sedikit berbeda dari CSF pada urutan fluid-attenuated inversion-recovery (FLAIR). Nodulnya isodense pada CT, isointense pada kedua gambar T1- dan T2-weighted, dan mengalami enhancement kuat dan homogen setelah injeksi media kontras. Menariknya, bagian padat memberikan sinyal rendah pada DWI dengan peningkatan nilai ADC, sebuah temuan yang biasanya tidak ditemukan pada tumor padat serebelar lainnya. Temuan ini dapat dijelaskan oleh ruang vaskular yang hadir dalam hemangioblastoma. Memang, rongga aliran yang menonjol di dan/atau di sekitar bagian padat dari tumor hipervaskular 
ini diamati pada beberapa kasus dan dapat mengarahkan diagnosis. Perfusion MRI juga mengungkapkan rasio rCBV tinggi pada lesi ini (sekitar 11), yang secara signifikan lebih tinggi daripada metastasis (sekitar 5). Sifat hipervaskular yang luas juga dikonfirmasi oleh angiografi serebral yang menunjukkan dilatasi arteri dan tumoral blush yang memanjang sesuai dengan bagian padat. Kateterisasi supraselektif pada pembuluh arteri memungkinkan embolisasi tumor sebelum operasi dan berpotensi menurunkan morbiditas dan mortalitas reseksi bedah. ${ }^{12}$
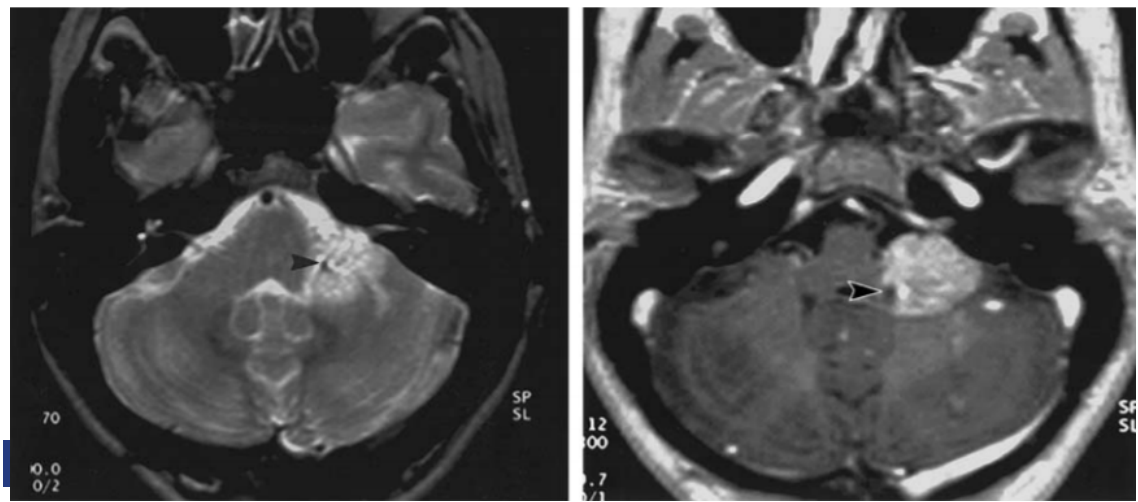

Gambar 18. Hemangioblastoma. Pada Wanita 28 tahun dengan penyakit von HippelLindau \& Vertigo. Gambar a. MRI T2WI tampak Lesi solid di CPA kiri dgn area flow void (anak panah) dan b. T1+C tampak penyangatan homogen. ${ }^{12}$

\section{e. Medulloblastoma}

Medulloblastoma adalah tumor neuroepitel primer yang terutama terjadi di garis tengah fossa posterior pada anak-anak. Perbedaan karakteristik pencitraan medulloblastoma dewasa telah dilaporkan, termasuk keterlibatan hemisfer serebelar lateral dengan kemungkinan keterkaitan ekstra-aksial, atau bahkan lokasi ekstra-aksial primer yang menyerupai meningioma atau vestibular schwannoma karena meluas ke saluran pendengaran internal. Medulloblastoma sangat seluler dan akibatnya tampak homogen isodense pada CT, isointense atau hypointense pada gambar T1- dan T2-weighted dan mengalami enhancement secara moderat setelah pemberian kontras. Penyimpangan pada 
antarmuka tumor otak mungkin menjadi petunjuk untuk asal intra-aksial dan diagnosis. CSF seeding sering terjadi dengan tumor yang sangat agresif ini, dan harus dicari dengan MRI di sepanjang neuraksis sebelum memulai pengobatan. Mungkin karena tingkat selulernya dan rasio nukleus-ke-sitoplasma yang tinggi, medulloblastoma menunjukkan intensitas sinyal yang tinggi pada DWI dan memiliki ADC yang rendah. Pada proton MR spectroscopy, medulloblastoma secara khas tampak menunjukkan taurin, dapat dideteksi pada waktu gema yang singkat, dan puncak kolin yang massif. ${ }^{13}$

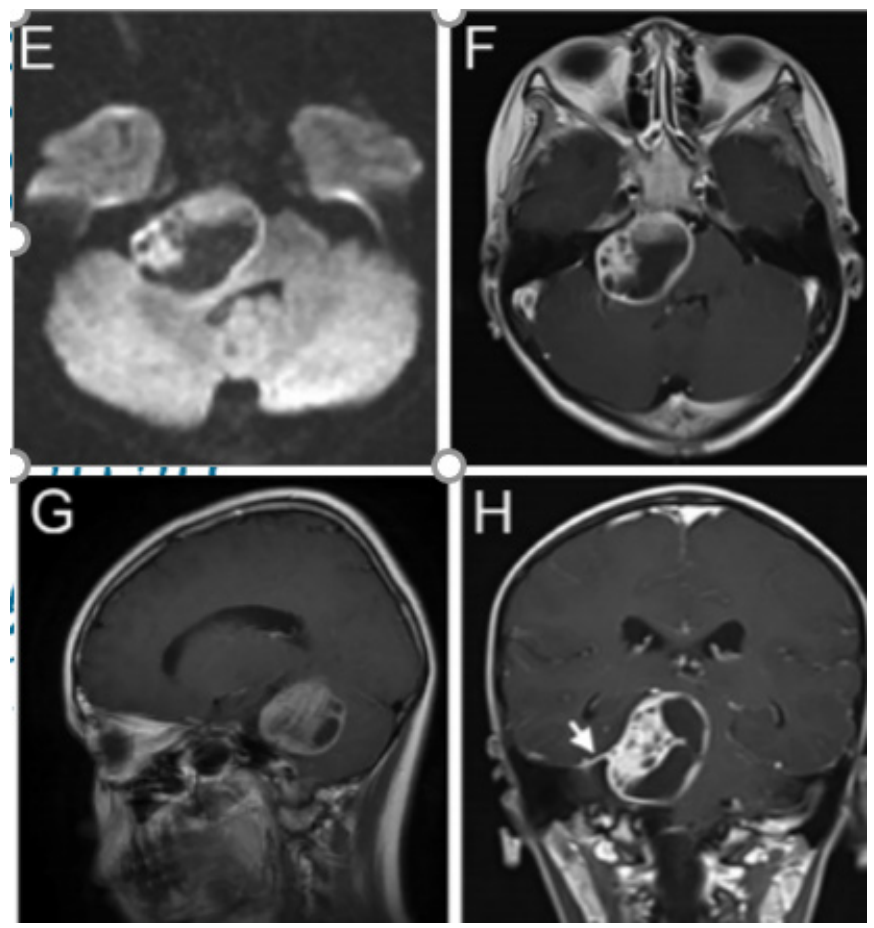

Gambar 19. Medulloblastoma. Pada DWI tampak restriksiDan pada T1+C tampak massa solid kistik di CPA kanan yang menyempitkan ventrikel IV. ${ }^{13}$ 


\section{Papiloma}

Kebanyakan papiloma pada orang dewasa terletak di fossa posterior. Meskipun biasanya timbul dari ventrikel keempat, papilloma terkadang dapat meluas ke CPA melalui foramen Lushka atau memang terjadi di sana. Papiloma pleksus koroid, yang jinak, secara struktural mirip dengan pleksus koroid normal dan oleh karena itu tampak sebagai massa yang terkalsifikasi, tervaskularisasi, yang mengalami enhancement pada CT, dengan kemungkinan kista intratumoral. Pada MRI, papiloma muncul sebagai tumor yang berbentuk seperti kembang kol, dapat bersifat homogen atau heterogen. Tampak iso/hipointens pada T1dan T2-weighted serta sangat mengalami enhancement setelah injeksi kontras, kecuali bila tumornya sangat terkalsifikasi. Papiloma mungkin juga mengandung area dengan intensitas sinyal rendah yang sesuai dengan kalsifikasi, kemungkinan ditemukan fokus intensitas sinyal tinggi karena perdarahan intratumoral dan celah aliran ketika pembuluh darah aliran tinggi mengarah ke tumor (Gambar 20). Cerebral digital subtraction angiogram menunjukkan arteri yang membesar yang menunjukkan vascular blush yang berkepanjangan dan intratumoral arteriovenous shunting, sehingga mirip hemangioblastoma di lokasi ini. Hidrosefalus sering dikaitkan dengan papiloma pleksus koroid; yang mungkin dapat dijelaskan oleh hipersekresi CSF oleh tumor, dan juga oleh obstruksi ventrikel keempat ketika tumor terletak di fossa posterior. ${ }^{13}$
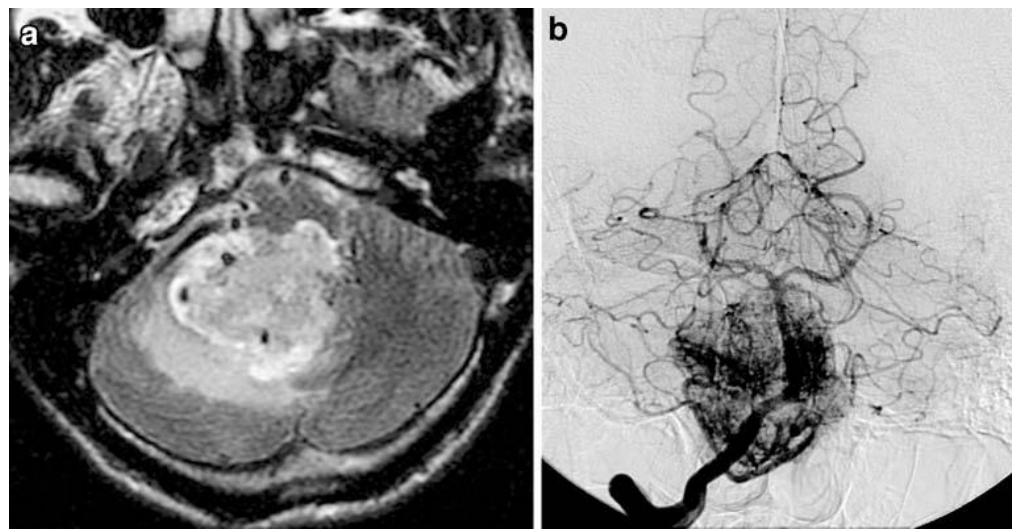

Gambar 20a, b Papiloma pada pria 28 tahun dengan vertigo dan sindrom hipertensi intrakranial. a. Gambar axial T2-weighted menunjukkan lesi intraventrikular besar yang terletak di bagian bawah ventrikel keempat yang meluas di CPA kanan melalui foramen kanan Lushka. Rongga aliran multipel yang diamati di dalam dan di sekitar lesi mendukung lesi hipervaskular, seperti yang dikonfirmasi oleh b. digital substracted angiogram, dengan fitur yang mengarah ke diagnosis papilloma pada lokasi ini. ${ }^{13}$ 


\section{g. Ependymoma}

Ependymoma ada di banyak area di sepanjang neuroaksis dan dapat ditemukan di spinal, supratentorial atau infratentorial, dengan predileksi pada ventrikel keempat di infratentorial. Ependymoma lebih sering ditemukan daripada papiloma, dapat meluas ke CPA melalui komponen eksofitik yang berasal dari ventrikel keempat melalui foramen Lushka, suatu pola yang sangat mendukung diagnosis. Ependymoma juga dapat muncul langsung di dalam CPA. Ependymoma muncul sebagai massa isodense tidak teratur dan berlobus dengan kalsifikasi generalisata di CT. Pada MRI, mereka tampak heterogen dengan hipointensitas T1, iso/hiperintensitas T2 dan mengalami enhancement yang heterogen. Ependymoma mungkin dapat menunjukkan gambaran mikrokista intratumoral, nekrosis atau perdarahan. Edema peritumoral biasanya tidak ada. ${ }^{14}$
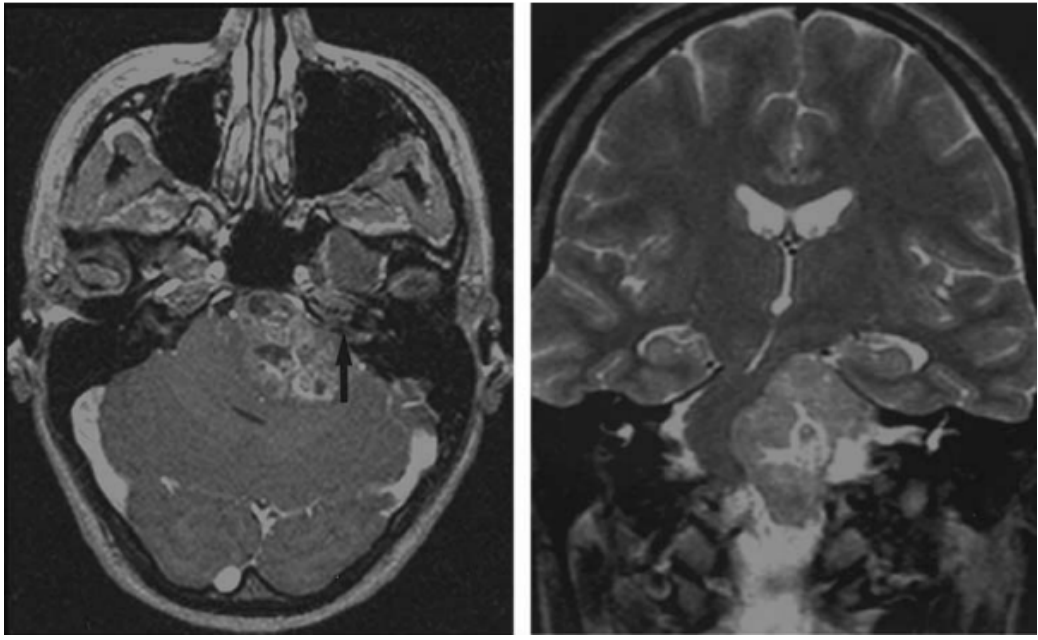

Gambar 21 Ependymoma. Wanita 24 tahun dengan vertigo, nyeri kepala, parese nervus facialis. Gambar a. T1+C tampak massa lobulated multikistik heterogen di CPA kiri, meluas ke IAC tanpa melebarkan. Gambar b. T2WI tampak danya efek massa pada brainstem. ${ }^{14}$ 


\section{Dysembryoplastic neuroepithelial tumour}

Dysembryoplastic neuroepithelial tumour (DNT) dijelaskan sebagai neoplasma klinikopatologis, biasanya terletak di lobus temporal, yang dikaitkan dengan kejang parsial kompleks yang sulit diatasi pada pasien muda. Laporan yang ada termasuk kasus yang jarang yang melibatkan fossa posterior, serta CPA di beberapa laporan acak. Diagnosis didasarkan pada analisis patologis tumor tetapi mungkin lebih ditekankan pada orang dewasa muda yang datang dengan gejala non-spesifik ringan yang berhubungan dengan lesi heterogen besar yang dapat meningkat. Massa tersebut juga dapat menimpa tulang yang berdekatan jika ada kontak dengan basis cranii. Tidak ada edema yang dilaporkan terkait dengan DNT infratentorial. ${ }^{13}$
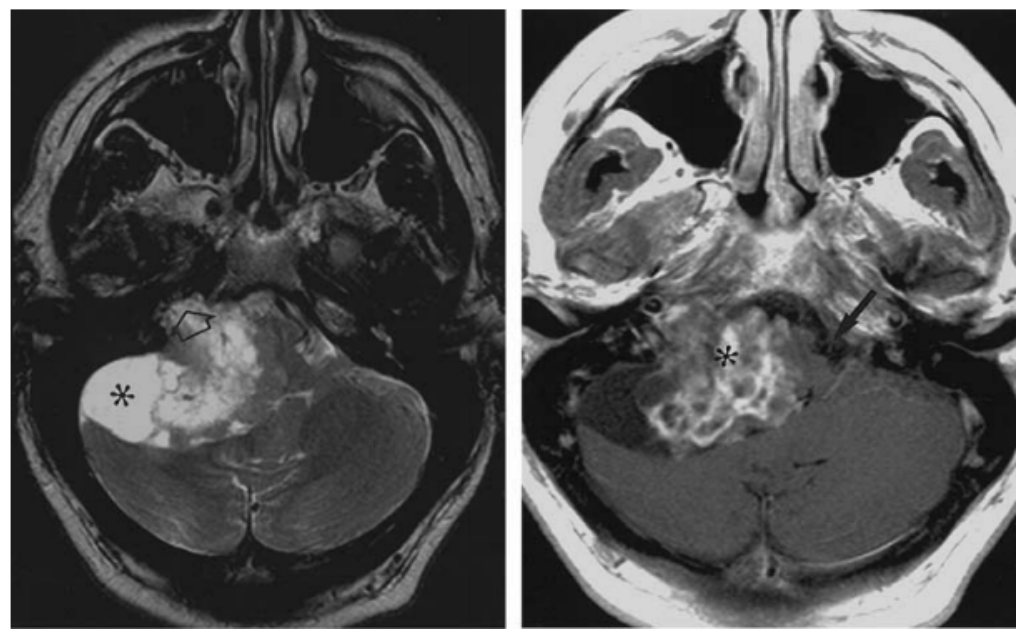

Gambar 22. Wanita usia 39 tahun dengan nyeri kepala terus menerus. Gambar a. T2WI tampak massa dengan komponen kistik, disertai erosi tulang (panah), tak tampak edema, b. $\mathrm{T} 1+\mathrm{C}$ tampak penyangatan pada jaringan hamartomatous $\left({ }^{*}\right)$, adanya efek massa pada CPA kanan. ${ }^{13}$ 


\subsubsection{Lesi Basis Cranii}

Beberapa tumor yang muncul dari basis cranii dapat meluas ke CPA, sebagian atau seluruhnya. Erosi tulang yang signifikan terkait dengan lesi massa menunjukkan diagnosis jenis lesi ini.

\section{a. Paraganglioma}

Sebagian besar paraganglioma yang terletak di CPA disebabkan oleh perluasan paraganglioma yang timbul di foramen jugularis (tumor glomus jugulare) atau di telinga tengah (tumor glomus tympanicum). Memang, hanya ada tiga kasus paraganglioma primer yang berasal dari CPA yang telah dilaporkan sampai saat ini. Tumor jinak tapi agresif lokal ini menghancurkan tulang basis cranii dengan pola erosi seperti dimakan ngengat di CT. Pada MRI, paraganglioma muncul sebagai lesi jaringan lunak yang sangat vaskular yang menunjukkan campuran beberapa tanda dan sinyal serpentin yang sesuai dengan pembuluh intratumoral aliran tinggi dan fokus intensitas sinyal tinggi karena perdarahan intratumoral dengan methemoglobin, menghasilkan penampilan "garam dan merica" yang khas (Gambar 17). Kombinasi unenhanced dan contrast enhanced 3D time-of-flight MR angiography telah diusulkan sebagai tambahan protokol pencitraan standar untuk meningkatkan deteksi pembuluh intratumoral ini. Perfusion MRI menunjukkan pola vaskularisasi tinggi dengan rCBV tinggi. Angiografi konvensional menunjukkan tumoral blush yang intens dengan arteri yang membesar, yang memungkinkan embolisasi hemostatik sebelum reseksi bedah, meskipun jarang digunakan sebagai modalitas diagnostik utama. ${ }^{14}$
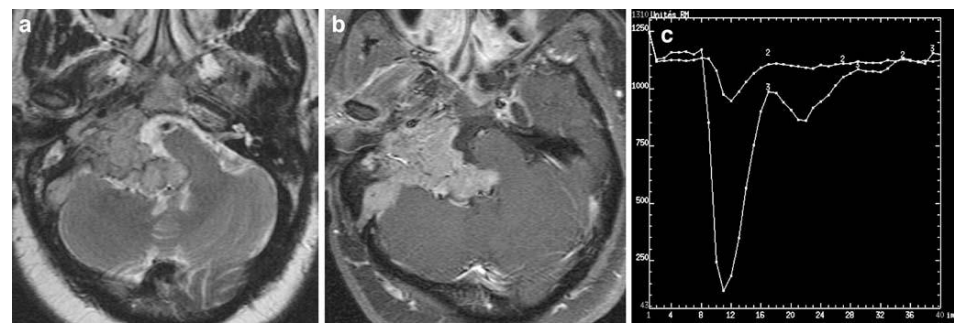

Gambar 23a-c Paraganglioma pada wanita 36 tahun dengan kelumpuhan wajah kanan, tinitus, vertigo dan kehilangan sensorineural. Sebuah Gambar aksial T2-weighted menunjukkan lesi massa hiperintens tebal yang melebarkan tangki CPA kanan, dengan beberapa rongga aliran di dalam dan di sekitar lesi. b Gambar berbobot T1 aksial yang disempumakan dengan Gadolinium dengan lemak di penekanan lebih baik menggambarkan luasnya tumor di dasar tengkorak dan foramen jugularis asalnya. c Pencitraan perfusi mengkonfirmasi hiperperfusi tumor, seperti yang diilustrasikan oleh volume darah otak relatif tinggi yang diamati pada kurva 3, dibandingkan dengan kurva normal $2 .{ }^{14}$ 


\section{Tumor kondromatous}

Kondroma dan kondrosarkoma berkembang dari sisa-sisa tulang rawan yang terbungkus dalam sinkondrosis basis cranii. Tumor ini biasanya berasal dari garis tengah, di fisura petroocciptal atau di dekat foramen jugularis, dan selanjutnya dapat meluas ke CPA (Gambar 24). Pada CT, tumor kartilago bersifat hipo-isoatenuasi, sering mengandung kalsifikasi dan sering merusak tulang yang berdekatan. Pada MRI, matriks tulang rawan hialin dari tumor ini memberikan intensitas sinyal yang rendah pada gambar dengan T1-weighted dan sinyal yang sangat kuat pada gambar T2-weighted. Diagnosis dapat dibuat dengan mudah ketika pola ini diamati di lokasi yang spesifik. Seringkali, area celah sinyal yang konsisten dengan kalsifikasi diamati di dalam massa. Tumor kondromatous biasanya berkembang dengan buruk karena hipovaskularitasnya. ${ }^{14}$
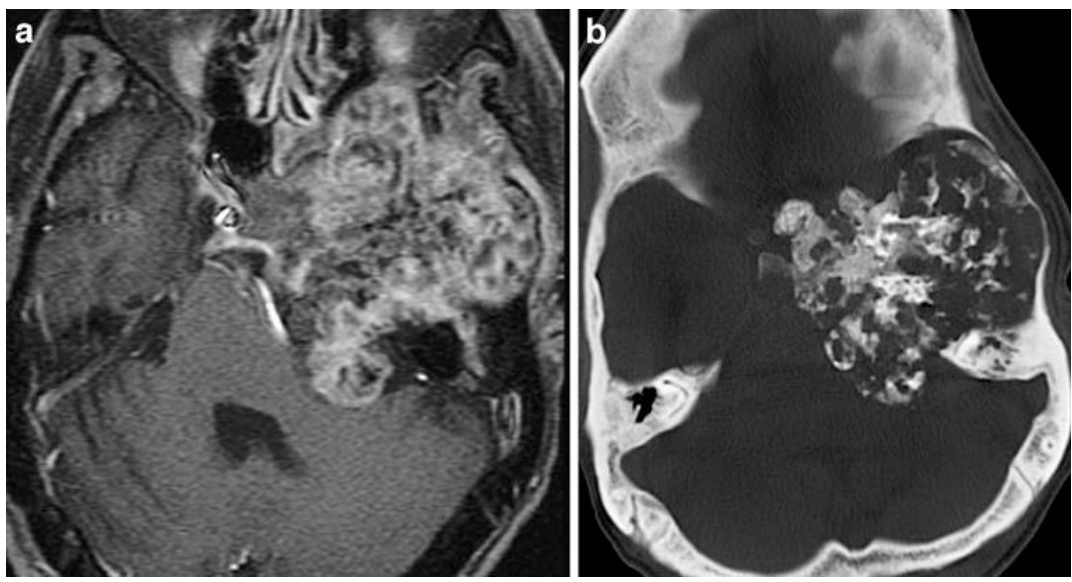

Gambar 24a, b Kondroma raksasa pada pria 33 tahun dengan sindrom hipertensi intrakranial, hemiparesia kanan dan afasia. a. Gambar dengan pembobotan T1 yang disempurnakan dengan gadolinium dengan penekanan lemak menunjukkan lesi heterogen besar dari dasar tengkorak yang meluas di fossa temporal dan CPA kiri. b. CT dengan algoritma tulang lebih baik menggambarkan kalsifikasi intratumoral masif, sesuai dengan beberapa fokus intensitas sinyal rendah yang terlihat pada Sebuah, dan sangat menunjukkan sifat chondromatous dari tumorous. ${ }^{14}$

\section{Chordoma}

Chordoma intrakranial diperkirakan berasal dari sisa-sisa embrionik dari notochord primitif dan terletak di garis tengah, dekat clivus, dan jarang meluas ke CPA. Chondroid 
chordoma adalah subtipe patologis chordoma yang mungkin memiliki asal lebih lateral di tulang petrosa dan tumbuh langsung di CPA. Namun, semua jenis kordoma memiliki pola pencitraan yang sangat mirip, kadang-kadang juga sama dengan kondrosarkoma, kecuali bahwa kondrosarkoma biasanya memiliki asal yang lebih lateral. Pada CT, chordoma intrakranial biasanya tampak sebagai massa jaringan lunak yang terletak di pusat, berbatas tegas, dan meluas terkait dengan kerusakan litik ekstensif pada klivus. Pada MRI, pada gambar MR T1-weighted, chordoma menunjukkan intensitas sinyal menengah hingga rendah, dengan fokus hiperintensitas sinyal T1 yang dapat mewakili fragmen osifikasi sisa dari basis cranii, kalsifikasi tumor, kumpulan cairan protein atau perdarahan. Pada gambar MR T2-weighted, mereka menunjukkan intensitas sinyal yang sangat tinggi dan beberapa bagian intensitas sinyal rendah yang dianggap karakteristik. Enhancement ringan biasanya diamati setelah pemberian media kontras. ${ }^{14}$

\section{d. Tumor kantung endolimfatik |}

Tumor kantung endolimfatik adalah tumor adenomatosa papiler agresif yang berasal dari kantung endolimfatik, yang terletak di aspek posterior tulang petrosa. Tumor ini dapat tumbuh cukup besar untuk meluas ke CPA dan akhirnya menekan batang otak. Tumor kantung endolimfatik terjadi secara sporadis atau dalam konteks von Hipple-Lindau disease. Tumor kantung endolimfatik adalah tumor ekstradural yang mengikis dan menghancurkan tulang petrosa retro labirin dengan batas berbentuk geografik atau pola "dimakan ngengat" pada CT, dan mungkin menunjukkan kemungkinan kalsifikasi. ${ }^{14}$

Pada MRI, lesi tampak heterogen pada gambar T1- dan T2-weighted, dengan fokus intensitas sinyal tinggi karena perdarahan subakut intratumoral. Mungkin ditemukan komponen kistik hiperintens pada T1 dan T2, kaya akan darah dan protein, dan menunjukkan diagnosis di lokasi yang sangat spesifik. Kista secara khusus bersifat predominan dan massa tumor ini dalam beberapa kasus bisa hampir sepenuhnya memberikan gambaran kistik. Pada massa yang berdiameter lebih besar dari $2 \mathrm{~cm}$, rongga aliran dapat diamati di dalam dan di sekitar tumor hipervaskular ini. ${ }^{14}$ 


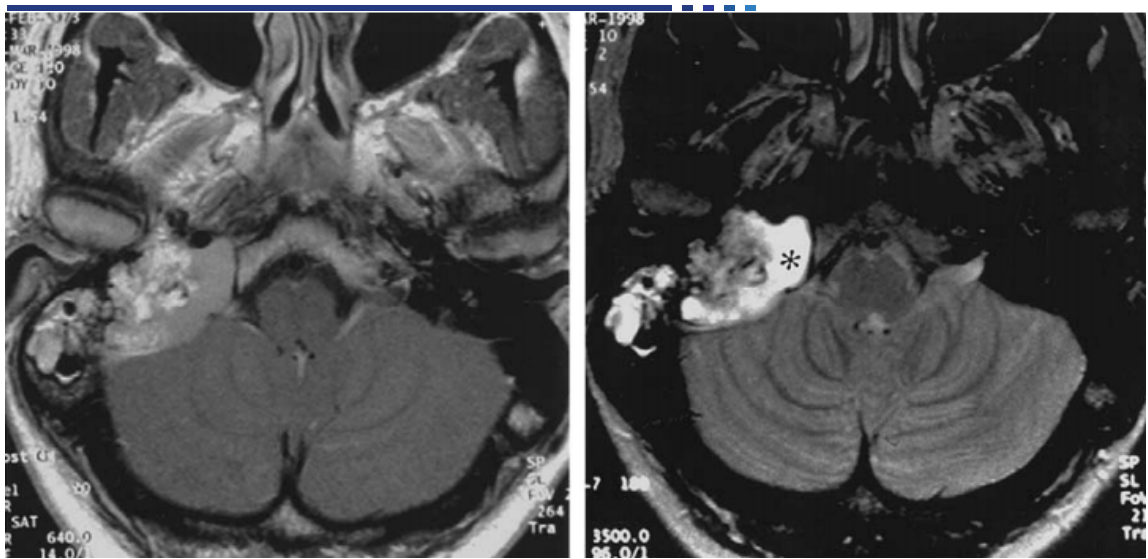

Gambar 25. Tumor kantung endolimfatik. Wanita 26 tahun dgn von Hippel Lindau disease dan vertigo. Gambar a. T1+C tampak tumor endolymph sac yang mendestruksi os temporalis dan meluas ke CPA dengan komponen darah dan kista berisi protein, b. T2WI tampak adanya komponen kistik dari tumor.

\subsubsection{Tumor yang Tidak Enhance}

\subsubsection{Lesi intensitas sinyal rendah pada TTV 1 I I}

\section{a. Kista epidermoid}

Kista epidermoid adalah lesi kongenital yang timbul dari inklusi jaringan epitel ektodermal secara tidak sengaja selama penutupan neural tube pada minggu-minggu pertama embriogenesis. Sekitar setengah dari kista epidermoid intrakranial yang terletak di cerebellopontine angle, di mana mereka mewakili 5\% dari keseluruhan lesi dan merupakan massa ketiga yang paling umum setelah vestibular schwannoma dan meningioma. Kista epidermoid adalah lesi yang tumbuh dari deskuamasi lambat dari epitel berlapis keratin yang melapisi kista. Massa lunak ini masuk ke dalam posterior fossa cistern, membungkus saraf kranial dan pembuluh darah dengan permukaan luar seperti kembang kol dengan lobus yang tidak teratur. Karena konsistensi relatif dari kista epidermoid dan kecenderungan mereka untuk hanya menempel dan tidak menggantikan struktur yang berdekatan, gejala klinis terjadi hanya ketika massa sudah berukuran besar. Kista epidermoid biasanya menimbulkan 
defisit saraf kranial dan khususnya neuralgia trigeminal, ekstensi ke Meckel's cave harus dicari dengan cermat, pada kasus kista epidermoid jarang ditemukan stroke batang otak karena peregangan cabang arteri basilar oleh lesi.

Pada CT, kista epidermoid tampak hipoatenuasi dengan kemungkinan kalsifikasi marginal. Pada MRI, mereka memiliki intensitas sinyal T1 rendah seperti pada cairan dan intensitas sinyal T2 tinggi, tetapi tampak sedikit lebih terang daripada CSF pada gambar T1- dan T2-weighted. Namun, mereka mungkin sulit dibedakan dari kista arachnoid berdasarkan intensitas sinyal saja. Dengan kemajuan teknik MRI, diagnosis pra operasi kista epidermoid dan perbedaan dengan kista arachnoid seharusnya tidak lagi menimbulkan dilema. Pada urutan FLAIR, kista epidermoid dapat dengan mudah dibedakan dari kista arachnoid karena kista epidermoid menunjukkan intensitas campuran iso hingga hipersinyal, tetapi dengan demarkasi yang buruk, sedangkan pada kista arachnoid menunjukkan sinyal yang ditekan, seperti sinyal CSF (Gambar 26). MR cisternography, dengan menggunakan urutan heavily T2-weighted 3D, memperlihatkan hipointens sinyal kista epidermoid pada CSF, yang menunjukkan margin tumor yang berlobus, dan dengan jelas menggambarkan hubungan anatomis dengan saraf dan pembuluh darah yang berdekatan dan dapat digunakan sebagai gambaran yang tepat untuk perencanaan bedah. DWI menawarkan temuan khusus untuk kista epidermoid ekstraaksial dengan menunjukkan sinyal yang sangat tinggi. ADC terbatas dibandingkan dengan CSF, hampir sebanding dengan otak, dan efek T2 shinethrough dimana keduanya memainkan peran penting dalam intensitas sinyal yang tinggi dari kista epidermoid di DWI. DWI juga penting dalam follow-up pasca operasi karena memungkinkan konfirmasi adanya kemungkinan tumor residual. Akhirnya, MR spectroscopy juga membantu karena hanya menunjukkan puncak laktat yang meningkat dalam tumor, yang dapat menjadi perhatian dalam kasus kista epidermoid atipikal. Memang, dalam sedikit kasus, terdapat pola kista epidermoid yang tidak biasa yang diamati pada MRI. Gambaran tersebut meliputi gambaran epidermoid putih yang memiliki kandungan protein yang kaya dan muncul dengan intensitas sinyal terbalik dengan intensitas sinyal tinggi yang homogen pada gambar T1-weighted dan intensitas sinyal rendah pada gambar T2weighted, perdarahan intracystic dengan intensitas sinyal heterogen karena produk darah atau transformasi ganas menjadi karsinoma sel skuamosa yang harus dipertimbangkan dalam kasus kontras enhancement yang nyata. ${ }^{12-15}$ 

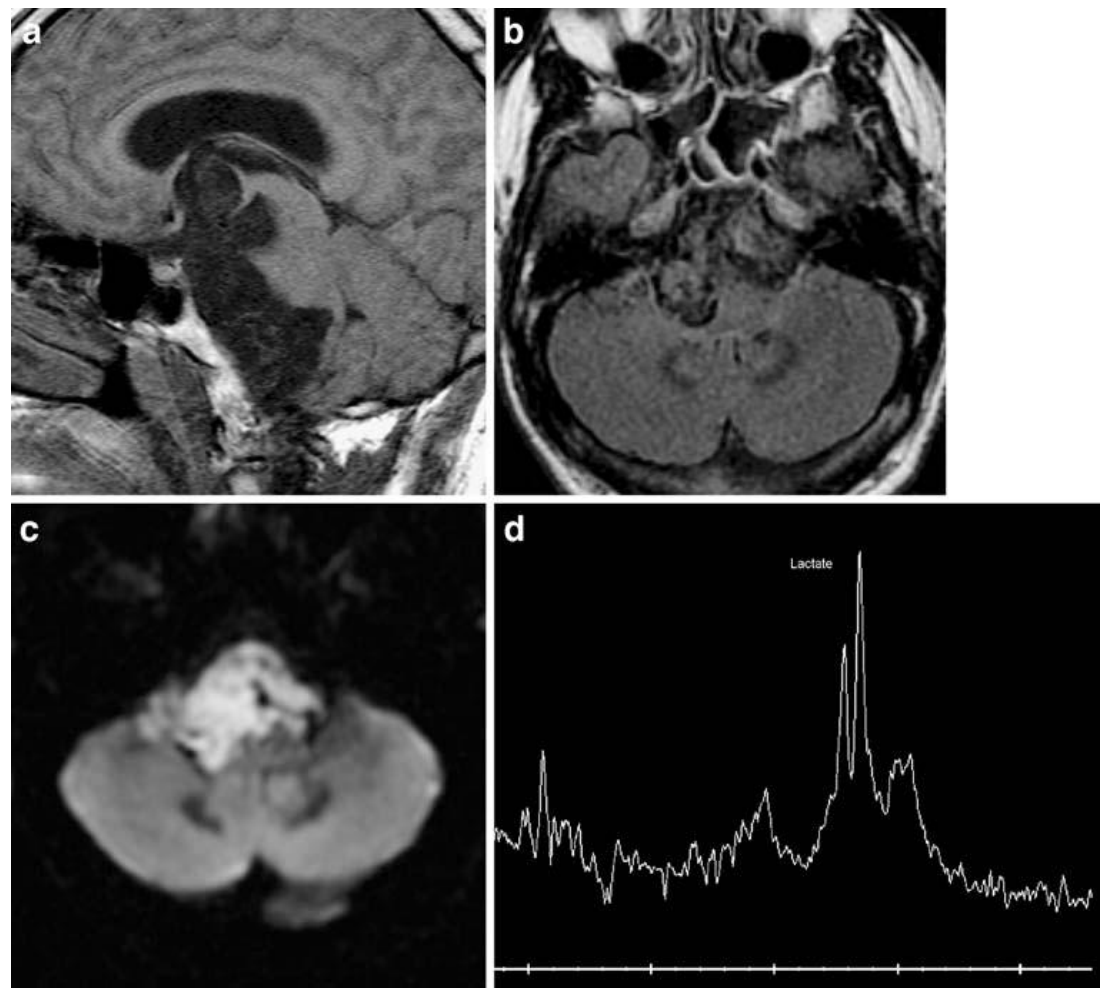

Gambar 26a-d Kista epidermoid pada pria 24 tahun dengan kelumpuhan saraf kranial. a. Gambar dengan sagital T1-weighted menunjukkan lesi ekstra-aksial hipointens tebal yang menjorok ke batang otak. b Pada FLAIR aksial, tumor muncul dengan intensitas

sinyal yang heterogen, berbeda dengan cairan serebrospinal. c DWI menunjukkan intensitas sinyal yang tinggi, ciri khas tumor epidermoid di lokasi ini. d MR spectroscopy menunjukkan puncak dominan dalam laktat, fitur sugestif lain dari kista epidermoid. ${ }^{15}$

\section{b. Kista arachnoid}

Kista arachnoid adalah lesi bawaan, jinak, menyerupai kantong intra-arachnoid yang berisi dengan cairan serebrospinal normal. Lokasi awal kista ini masih tidak pasti, akan tetapi kista arachnoid bisa dihasilkan dari pemecahan meningen embrionik. Kista ini biasanya supratentorial, dengan sekitar 70\% berada di fossa temporal, sebagian besar di sisi kiri, di depan temporal pole. Hanya 10\% dari kista arachnoid terletak di fossa posterior, di mana mereka paling sering berkembang di CPA. Sebagian besar kista arachnoid tidak 
menunjukkan gejala dan ditemukan secara kebetulan pada pencitraan, tetapi mereka dapat membahayakan fungsi saraf kranial di fossa posterior dengan meregangkannya. Perdarahan intrakistik spontan atau traumatis juga dapat mempersulit kista arachnoid, meskipun hal ini jarang ditemukan di fossa posterior. Pada neuroimaging, atenuasi dan intensitas sinyal dari kista arachnoid tanpa komplikasi sama persis dengan CSF pada semua urutan, tidak mengalami enhancement setelah pemberian media kontras, dan oleh karena itu, dapat meniru kista epidermoid pada gambar konvensional T1- dan T2-weighted. Namun, kista arachnoid biasanya mengambil alih lokasi arteri dan saraf kranial yang berdekatan daripada membungkusnya, seperti yang biasanya dilakukan oleh kista epidermoid. Mereka juga menunjukkan tepi yang membulat, dan dengan halus mengubah bentuk otak atau struktur tulang yang berdekatan. Selain itu, penekanan lengkap intensitas sinyal pada urutan FLAIR pada kista arachnoid dan kurangnya pembatasan difusi lesi pada DWI dapat menyingkirkan kista epidermoid sebagai diagnosis banding dari kista arachnoid (Gambar 27). ${ }^{16}$
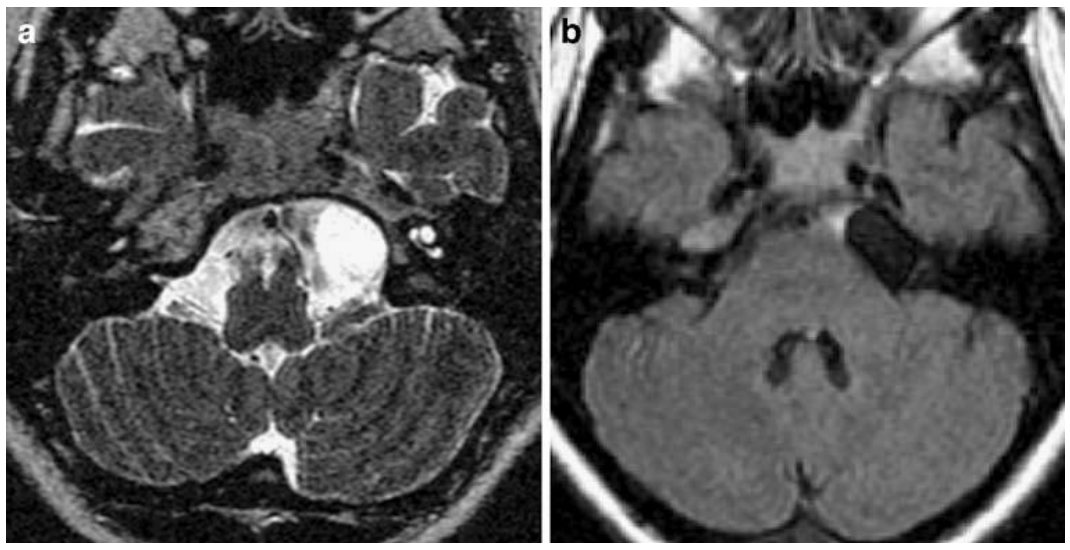

Gambar 27a, b Kista arachnoid pada wanita 16 tahun dengan sakit kepala. a. Gambar axial infra-milimetric T2-weighted menunjukkan lesi hiperintens bulat yang berbatas tegas di CPA kiri yang mengikis dasar tengkorak dengan mulus. b Pada urutan FLAIR, sinyal kista arachnoid tampak benar-benar tertekan, bahkan lebih dari CSF bebas yang berdenyut di depan batang otak. ${ }^{16}$ 


\section{c. Neurosistiserkosis |||}

Neurosistiserkosis, parasitosis karena Taenia solium, dapat hadir dalam bentuk racemose dengan beberapa kista subarachnoid non-enhancing, kadang-kadang terletak di CPA. Mereka muncul sebagai kista lobulated tanpa nodul mural, non-enhancing dan memiliki intensitas sinyal yang mirip dengan CSF, yang menjadikan kista arachnoid sebagai diagnosis banding utama. Kurangnya erosi tulang yang berdekatan dengan kista sangat membantu dalam membedakan kondisi ini, dan diagnosis neurosistiserkosis kemudian harus dipertimbangkan pada pasien dari daerah endemik. Pada DWI, kista neurosistiserkosis memiliki sinyal hipointens dengan koefisien difusi yang mirip dengan CSF. DWI mungkin gagal untuk mendeteksi lesi racemose. Sebagai alternatif, MR cisternography noninvasif melalui urutan FLAIR yang diambil setelah inhalasi 100\% O2 selama 5 menit, yang meningkatkan sinyal CSF normal, telah diusulkan sebagai teknik yang kuat untuk mendeteksi lesi sistiserkosis subarachnoid. ${ }^{17}$

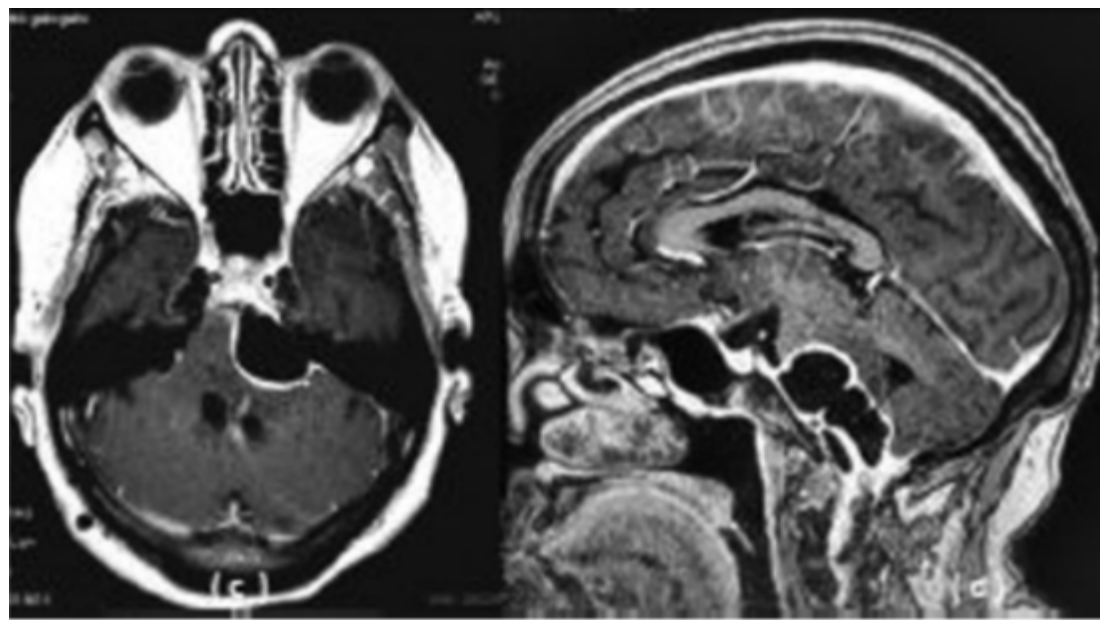

Gambar 28. Neurosistiserkosis. Wanita 58 tahun dengan keluhan sakit kepala dan paresis nervus kranialis kiri. Gambar a. T1WI tampak lesi kistik hipointens, b. T1+C FS tampak lesi multilocular dengan peripheral contrast enhancement. ${ }^{17}$ 


\subsubsection{Lesi intensitas sinyal tinggi pada TIWI}

Intensitas sinyal tinggi T1 intrinsik dari lesi massa CPA non-enhancing memiliki kandungan lemak atau protein tinggi. Urutan T1-weighted dengan penekanan sinyal lemak harus dilakukan untuk membedakan sifat yang tepat dari intensitas sinyal yang tinggi: jika terjadi penekanan, maka tumor mengandung lemak dan kemungkinan merupakan lipoma atau kista dermoid, jika tidak berubah, lesi memiliki kandungan protein yang tinggi dan dapat berupa kista neurenterik atau granuloma kolesterol. ${ }^{18}$

\section{a. Lipoma}

Lipoma adalah lesi jinak yang diyakini sebagai hasil dari maldiferensiasi meninx primitif. Mayoritas lipoma intrakranial terletak di sekitar corpus callosum dan sekitar 100 kasus telah diamati di CPA, di mana mereka membungkus struktur neurovaskular normal yang berdekatan dengan adhesi yang sangat padat. Lipoma intrakranial mungkin asimtomatik, secara kebetulan ditemukan pada pencitraan otak. Mereka juga dapat menghasilkan gejala dengan menekan struktur otak yang berdekatan, seperti saraf kranial di CPA. Pada pencitraan, lipoma tampak sama persis dengan lemak subkutan: tampak hipoatenuasi homogen pada CT (kecuali untuk kemungkinan kalsifikasi superfisial) dan dengan intensitas sinyal yang sangat tinggi homogen pada gambar T1-weighted, yang menurun pada gambar dengan supresi lemak, sementara tidak ada enhancement yang diamati setelah pemberian kontras. ${ }^{17}$
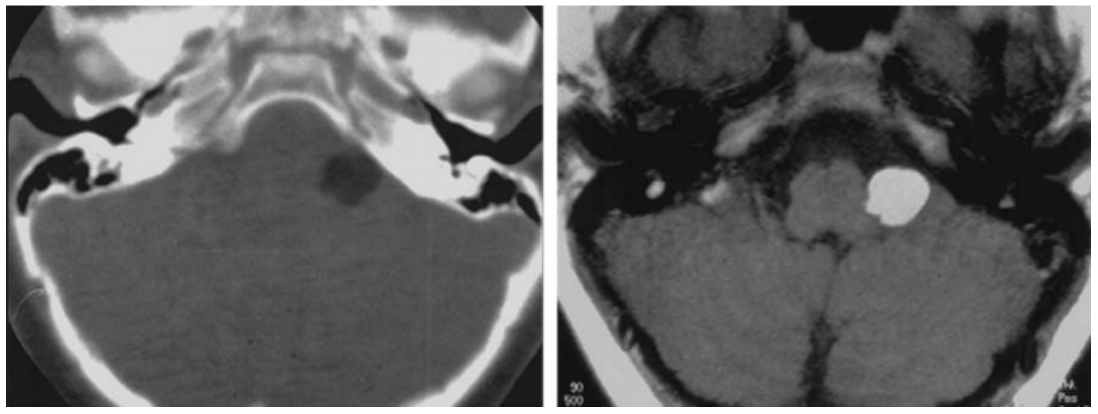

Gambar 29. Lipoma. Pada wanita 7 tahun pada Gambar a. CT tampak lesi hipodens batas tegas di CPA kiri, b. MRI T1WI tampak lesi hiperintens dengan intensitas yang mirip dengan lemak subkutan. ${ }^{17}$ 


\section{b. Kista dermoid}

Kista dermoid dihasilkan dari inklusi kongenital ektoderm kulit. Kista dermoid intrakranial adalah kista lesi ekstra-aksial intradural, terutama supratentorial dekat garis tengah. Kista dermoid jarang terjadi di CPA, dan mungkin sekunder akibat perluasan lesi parasellar ke kaudal, lokasi intrakranial yang paling sering terjadi kista ini. Kista dermoid adalah massa heterogen yang mengandung campuran lemak, rambut, kalsifikasi dan produk kelenjar sebaceous dan deskuamasi epitel keratin. Pada pencitraan, kista dermoid muncul sebagai massa bulat berlemak yang berbatas tegas dengan kapsul perifer tebal yang dapat membesar. Dalam kasuS ruptur, visualisasi droplet lemak T1-hiperintens di sulkus atau fatfluid level di ventrikel sangat mendukung diagnosis (Gambar 30). ${ }^{18}$
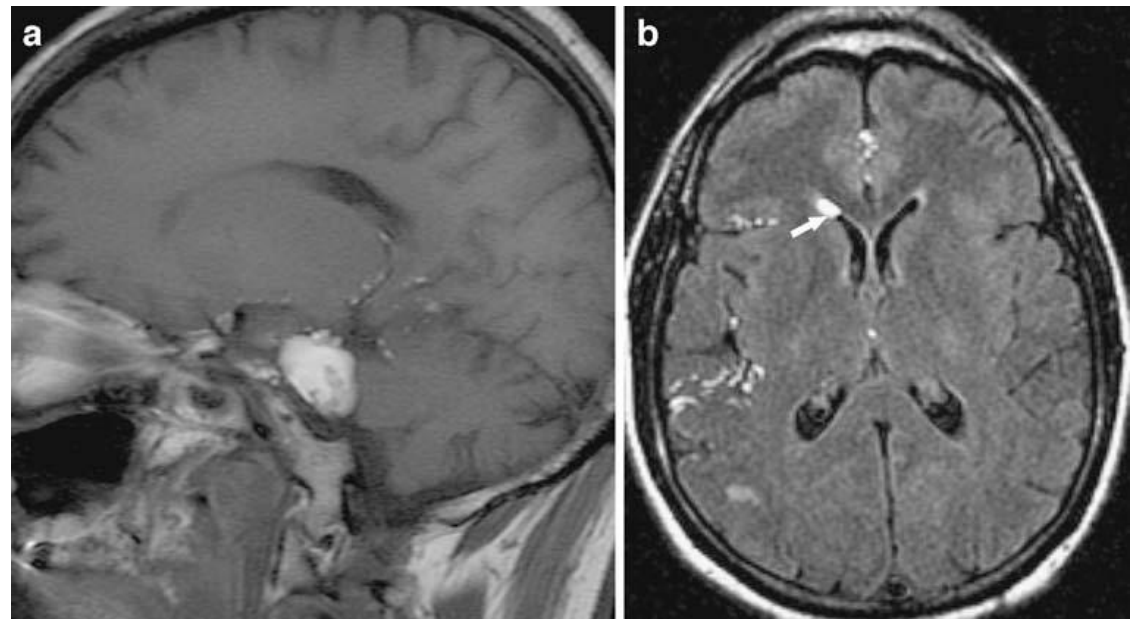

Gambar 30. Kista dermoid yang pecah pada pria 50 tahun dengan sakit kepala mendadak.

a. Gambar sagital T1-weighted menggambarkan lesi CPA hiperintens heterogen yang besar dan beberapa fokus subarachnoid halus dengan intensitas sinyal tinggi yang konsisten dengan tetesan lemak. b. Gambar FLAIR aksial menunjukkan beberapa tetesan lemak di sulkus supratentorial, serta tingkat cairan lemak di tanduk frontal kanan (panah), fitur yang sangat mendukung diagnosis. ${ }^{18}$ 


\section{Kista neurenterik}

Kista neurenterik adalah massa kistik kongenital yang dilapisi oleh epitel penghasil musin yang berasal dari endodermal menyerupai mukosa saluran cerna. Kista neurenterik yang berdekatan dengan sistem saraf pusat sebagian besar terlihat di dalam kanal tulang belakang, ventral ke sumsum tulang belakang. Kista neurenterik intrakranial sangat langka, biasanya terletak di dekat garis tengah di fossa posterior atau di CPA. Kista ini hadir dengan margin bulat dan halus. Intensitas sinyal kista tergantung pada kandungan proteinnya. Jarang dapat meniru CSF normal saat konten protein rendah, tetapi seringkali isointense hingga hyperintense relatif terhadap parenkim otak pada gambar T1-weighted dan hiperintens pada gambar T2-weighted ketika konsentrasi protein tinggi. Kista neurenterik sangat jarang menunjukkan enhancement pada tepi perifer. Perbedaan ada dalam intensitas sinyal pada DWI dan nilai ADC dari kista neurenterik. Namun, berdasarkan beberapa kasus yang diamati pada DWI, tampaknya intensitas sinyal rendah dari kista neurenterik lebih menonjol pada urutan ini (Gambar 31). Fitur pencitraan ini memungkinkan diferensiasi dari kista epidermoid, yang mungkin menunjukkan intensitas serupa pada urutan konvensional, namun DWI dapat menunjukkan karakteristik intensitas sinyal tinggi. ${ }^{19}$
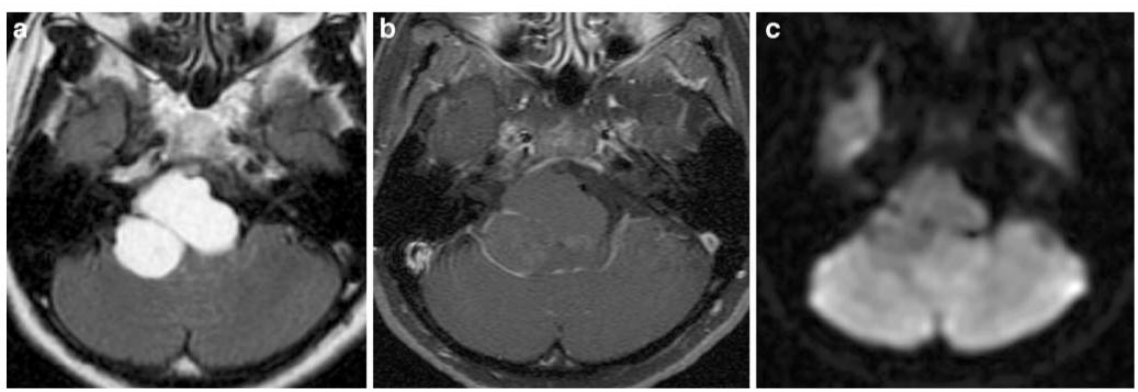

Gambar 31. Kista neurenterik pada pria 46 tahun dengan kelumpuhan saraf kranial. a. Gambar FLAIR aksial mengungkapkan massa kistik di CPA kanan dengan margin halus dan sinyal hiperintens homogen yang tidak biasa. b. Gambar dengan axialT1weighted yang mengalami enhancement dengan kontras dengan penekanan lemak hanya menunjukkan linear periferal yang halus peningkatan yang dihentikan pada tepi posterior

lesi intensitas sinyal iso ini. c. Pada gambar dengan DWI, lesi tidak menunjukkan intensitas sinyal yang tinggi seperti kista epidermoid, tetapi muncul dengan isointensitas, tentunya karena efek T2 shine-through dan ADC yang tinggi $\left(2.00010-3 \mathrm{~mm}^{2} / \mathrm{s}\right){ }^{19}$ 


\section{d. Granuloma kolesterol}

Granuloma kolesterol terjadi karena obstruksi kronis sel-sel udara dan akumulasi sekresi.

Dalam kasus yang berasal dari apeks petrosa, granuloma ini dapat menjadi cukup besar untuk berkembang di CPA di mana mereka dapat membahayakan saraf kranial. granuloma kolesterol muncul sebagai lesi litik ekspansif pada tulang temporal dengan margin yang tajam dan halus, dimana wilayah tengah menunjukkan intensitas sinyal tinggi dan tepi hipointens perifer pada gambar T1- dan T2-weighted, yang sesuai dengan hubungan tulang kortikal yang diperluas dan deposit hemosiderin (Gambar 32). Ketika kering, granuloma kolesterol dapat menunjukkan area dengan intensitas sinyal rendah yang memberikan lesi T1-hiperintens homogen ini pola T2 heterogen yang sangat mendukung diagnosis di lokasi ini. Granuloma kolesterol dapat diklasifikasikan sebagai lesi basis cranii yang menginvasi CPA, tetapi biasanya kurangnya enhancement setelah pemberian kontras dan karakteristik intensitas sinyal tinggi T1 intrinsiknya, membuat klasifikasi dalam kategori ini lebih relevan. ${ }^{20}$
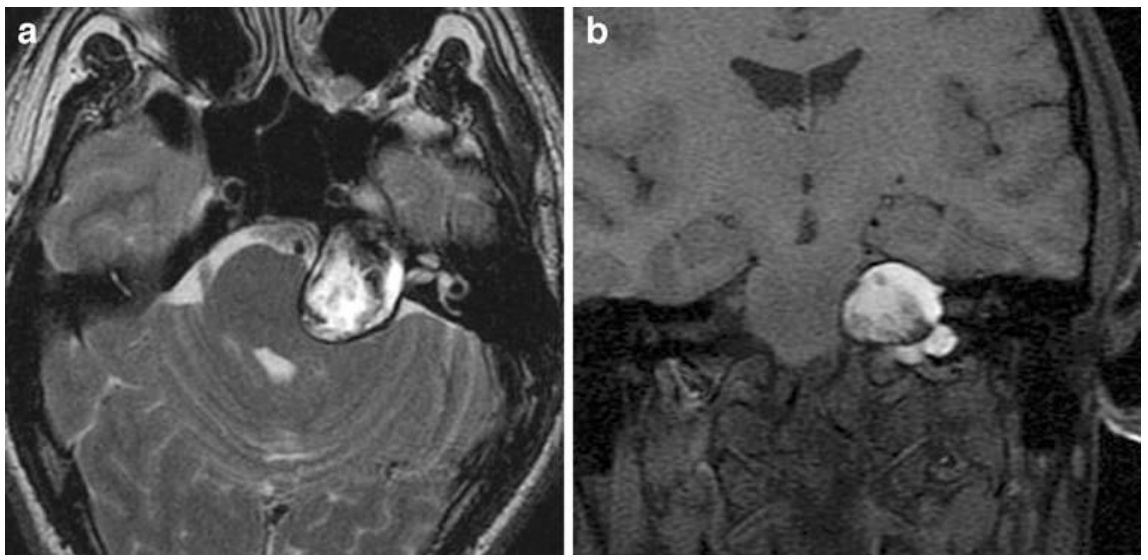

Gambar 32. Granuloma kolesterol pada pria 34 tahun dengan neuralgia trigeminal kiri. a. Gambar axial T2-weighted mengungkapkan lesi apeks petrosa dengan inti intensitas sinyal tinggi yang khas dikelilingi oleh tepi hipointens yang mewakili tulang kortikal yang meluas dan deposit perifer hemosiderin. b. Gambar coronal T1-weighted yang ditekan lemak menunjukkan persistensi intensitas sinyal tinggi pusat pada urutan ini, yang menunjukkan kandungan protein tinggi daripada lemak, fitur yang menunjukkan granuloma kolesterol di lokasi spesifik ini. ${ }^{20}$ 


\section{BAB III \\ PENUTUP}

Berbagai macam tumor dapat ditemukan di CPA. Pemeriksaan yang teliti dari tempat asal, bentuk, kepadatan, intensitas sinyal dan karakteristik tumor setelah injeksi media kontras memungkinkan pendekatan sistematis untuk diagnosis pra operasi di sebagian besar kasus. Peran MRI dengan pencitraan difusi dan perfusi, serta MR spectroscopy dapat memberikan informasi penting yang disajikan oleh ahli Radiolog sampai pada diagnosis yang benar secara non-invasif. 


\section{DAFTAR PUSTAKA}

1. James G, Smirni P, Chang Y, Elisabeth R. Cerebellopontine Angle Masses: Radiologic Pathologic Correlation. RSNA Journal. 2015:13(1): 1131-1147.

2. Fabrice B, Julien S, Jacques Chiras. Imaging of Cerebellopontine Angle Lesions: An Update. European Radiology Journal. 2017:17(1): 2472-2482.

3. Maheswararao Y, Rama K. MRI Evaluation of Extra Axial Cerebello Pontine Angle Tumours. International Journal of Contemporary Medicine Surgery and Radiology. 2018:3(3): 33-38.

4. Fabrice B, Jean L, Kathlyn M, Clement I, MD, Yves S, Dominique D, Jean F. Unusual Lesions of the Cerebellopontine Angle: A Segmental Approach. RSNA Journal. 2018:21(1): 419-438.

5. James R. Imaging of Cerebellopontine Angle Masses. American Journal Radiology. 2016:1: 195-201.

6. Pratiksha Y, Mansi J, Dhaval T. Magnetic Resonance Imaging of Cerebellopontine Angle Lesions. Medical Journal of Dr. D.Y. Patil University. 2015:1: 751-759.

7. Scheau, Lupescu, Popa E, Preda. Cerebellopontine Angle Masses: MRI Technique, Positive and Differential Diagnosis. European Society of Radiology: 2015:1:1-25.

8. Nikdokht F. Imaging of Vestibular Schwannoma and Other Cerebellopontine Angle Tumors. Operative Techniques in Otolaryngology. 2015:25 (1): 80-90.

9. Biswas P, Sardar M, Saha G, Hossain M, Hossain M, Paul T, Azad K. Evaluation of Extra Axial Cerebellopontine Angle Tumours Through MRI. Journal Dhaka Medical College. 2018:27(2): 90-100.

10. Hagos Bi, Tigist K, Tequam D. Cerebellopontine Angle Masses: RadiologicPathology Correlation at Tikur Anbessa Specialized Hospital and Myungsung Christian Medical Center. Ethiopian Medical Journal. 2018:56(1): 35-42.

11. Aijaz AH, Irshad M. MRI in Cerebellopontine Angle and Internal Auditory Canal Lesions. IAIM, 2018:5(12): 40-50.

12. Mulkens TH, Parizel PM, Martin JJ. Acoustic Schwannoma: MR Findings in 84 Tumors. American Journal Radiology. 2016:160(1): 395-398.

13. Jeng CM, Huang JS, Lee WY. Magnetic Resonance Imaging of Acoustic Schwannomas. Journal of Formos Medical Association. 2015:94: 487-493.

14. Press GA, Hesselink JR. MR Imaging of Cerebellopontine Angle and Internal Auditory Canal Lesions at 1.5 T. American Journal Radiology. 2016:150(1): 1371- 
1381.

15. Weber AL. Magnetic Resonance Imaging and Computed Tomography of The Internal Auditory Canal and Cerebellopontine Angle. Israel Journal Medical Science. 2015:28: 173-182.

16. Beutow MP, Burton PC. Simirniotopoulos JG: Atypical and Misleading Features in Meningiomas. RSNA. 2015:11: 1087-1100.

17. Arseni C, Dumitrescu L. Neurinomas of The Trigeminal Nerve. Surgical Neurology Journal. 2015: 4: 497 -503.

18. Bordi L, Compton J, Symon L. Trigeminal Neuroma: A Report of 11 Cases. Surgical Neurology Journal. 2018:31: 272-276.

19. Weissman JL, Hirsch BE. Imaging of Tinnitus A Review. Radiology Journal. 2017:216: 342-349.

20. Tali ET, Yuh WTC, Nguyen HD. Cystic Acoustic Schwannomas: MR Characteristics. AJNR. 2015:14: 1241-1247. 


\title{
Dr. Firman Parulian Sitanggang, Sp.Rad(K)RI, M.Kes
}

Lahir di Surabaya tahun 1961. Menyelesaikan pendidikan dokter umum di FK UKI tahun 1990, pendidikan spesialis radiologi di FK UNAIR RS Dr. Soetomo Surabaya tahun 2004.

Konsultan Radiologi Intervensi dari Kolegium Radiologi Indonesia tahun 2009.

Magister Kesehatan dari Pascasarjana FK UNUD tahun 2020.

\section{Saat ini jabatan yang diemban adalah :}

1. Ketua Departemen Radiologi FK UNUD RSUP Sanglah Denpasar

2. Lektor pada Prodi Sp-1 Radiologi FK UNUD

3. Dokter Pendidik Klinis Ahli Utama pada Departemen/KSM Radiologi RSUP Sanglah Kementrian Kesehatan Republik Indonesia

\author{
S
}

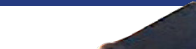




\section{PERAN MRI DALAM PENCITRAAN DIAGNOSTIK TUMOR CEREBELLOPONTINE ANGLE (CPA)}

Perkembangan ilmu pengetahuan dan teknologi telah membawa kemajuan yang sangat pesat di berbagai bidang. Tumor CPA secara klinis tidak spesifik dan gojala yang muncul tidak terkait dengan sifat lesi itu sendiri, tetapi berhubungan dengan struktur neurovaskular atau struktur otak yang terlibat dengan lesi terscbut. Diagnosis mungkin sulit dibuat karena berbagai jenis sel dan asal tumor tersebut. Olch karena tumor CPA yang berasal dari spektrum yang sangat luas sehingga menjadi tantangan dalam penegakkan diagnosis. Untuk dapat mencakup scluruh spektrum tumor yang berpotensi ditemukan di CPA, maka diperlukan pencitraan neuroimaging terkait yang perlu diketahui oleh ahli radiologi untuk membuat diagnosis yang relevan secara klinis dalam menegakkan diagnosis pra operasi yang lebih akurat.

Buku ini dapat dijadikan buku ajar bagi mahasiswa Program Pendidikan Dokter Spesialis (PPDS) dan Dokter Muda di Departemen Radiologi dengan harapan dapat memberikan manfaat dalam menangani kasus-kasus dengan kecurigaan tumor di regio CPA.
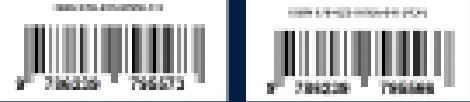